\title{
Глава 2
}

\section{ПОСТКОЛЛИЗИОННЫЕ ИНТРУЗИИ КОКШААЛЬСКОГО СЕГМЕНТА ЮЖНОГО ТЯНЬ-ШАНЯ}

\section{§ 2.1. Геологическое строение и главные типы постколлизионных гранитоидов Кокшаала}

Кокшаальский сегмент Южного Тянь-Шаня, расположенный на территории Кыргызстана и Северо-Западного Китая, охватывает восточную часть пояса герцинид, находящуюся к востоку от Талассо-Ферганского разлома (рис. 2.1). Особенностью геологического строения Кокшаала является наличие серии тектонических покровов, продвигавшихся к югу в течение среднего карбона ранней перми в ходе коллизии Киргизско-Казахского и Таримского континентов [Бискэ, 1996].

В строении Кокшаальского сегмента выделяются три главных тектонических единицы (рис. 2.2). Верхние покровы сложены образованиями аккреционной призмы, включающими девонские и карбоновые турбидиты, кремни

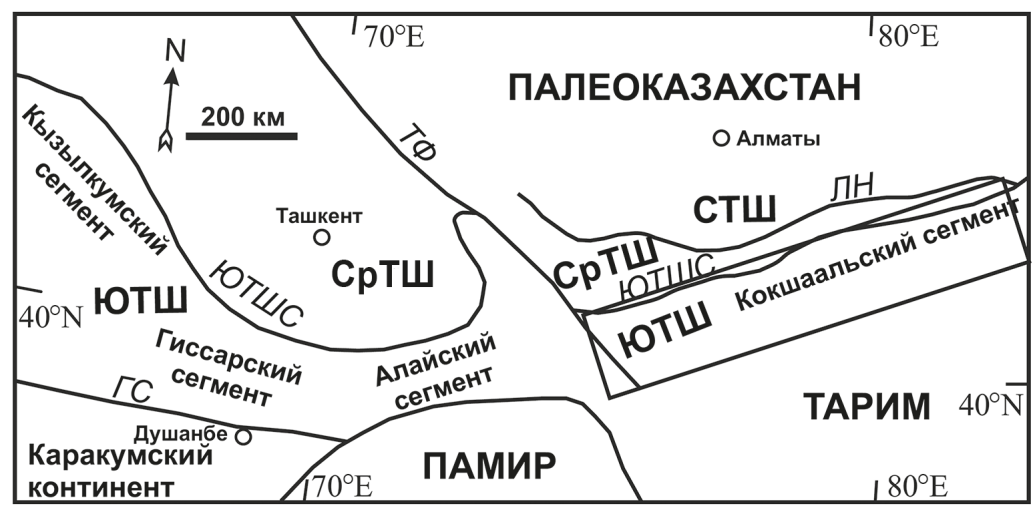

Pис. 2.1. Изученный район в Кокшаальском сегменте Южного Тянь-Шаня на схеме тектонического строения западного Тянь-Шаня:

СТШ - Северный Тянь-Шань, СрТШ - Срединный Тянь-Шань, ЮТШ Южный Тянь-Шань, ЛН - линия Николаева, ТФ - Таласо-Ферганский разлом, ЮТШС - Южно-Тянь-Шаньская сутура, ГС - Гиссарская сутура 


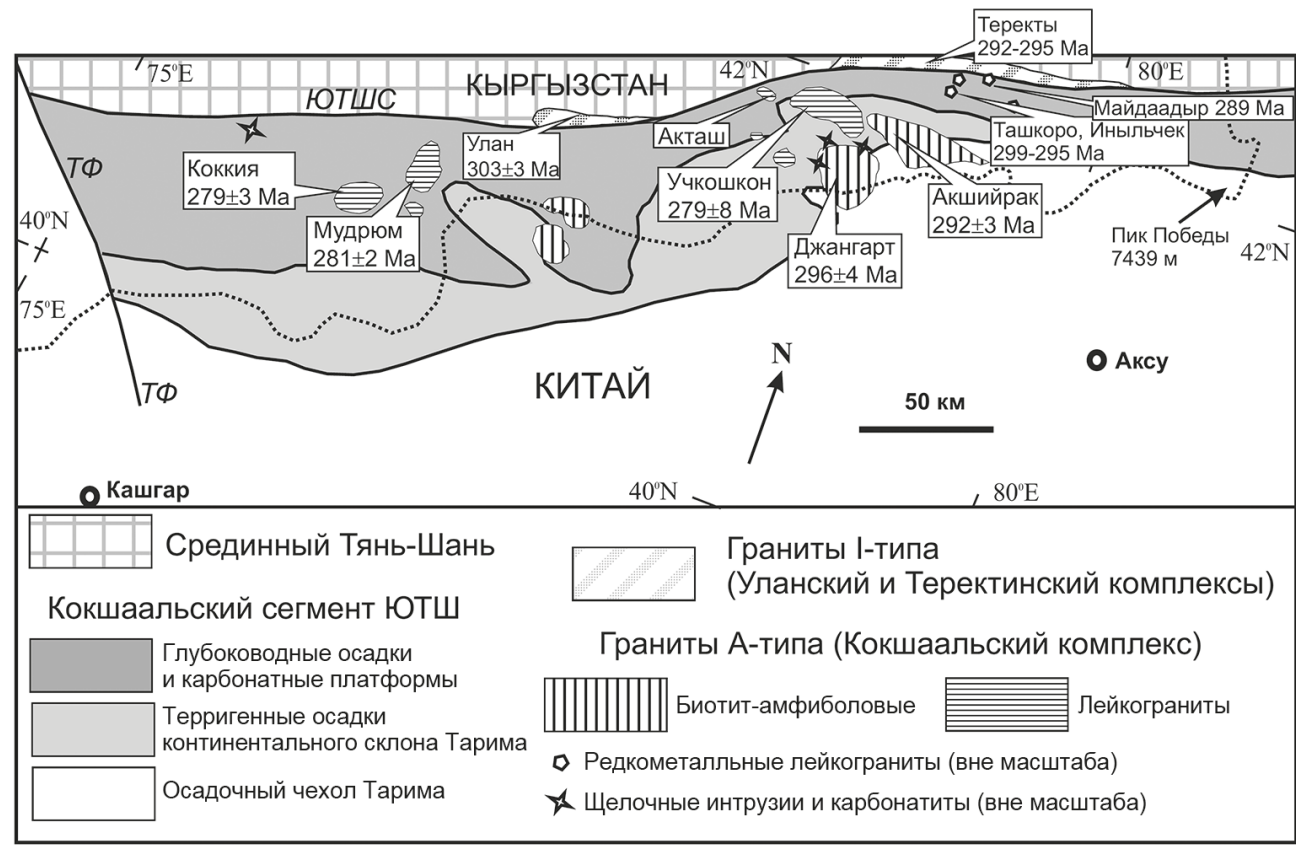

Рис. 2.2. Геологическая схема Кокшаальского сегмента Южного Тянь-Шаня с результатами датирования изученных интрузий:

ТФ - Таласо-Ферганский разлом, ЮТШС - Южно-Тянь-Шаньская сутура (Атбаши-Иныльчекский разлом)

и карбонатные платформы преддугового прогиба, а также обдуцированные фрагменты офиолитов. Эти образования аккреционной призмы надвинуты на верхнепалеозойские кластические осадки пассивной окраины Тарима. Этот комплекс терригенных осадков континентального склона Тарима с юга ограничен формациями палеозойского осадочного чехла внутренней части Таримского континента. Отложения аккреционного комплекса и осадки континентального склона интенсивно деформированы, сорваны и надвинуты в южном направлении на докембрийский фундамент Тарима. Атбаши-Иныльчекский разлом, являющийся частью Южно-Тянь-Шаньской сутуры, отделяет в современной структуре эту покровную серию от северного Киргизско-Казахского палеоконтинента, то есть Срединного Тянь-Шаня, и представляет собой зону, в которой первично сформировавшийся офиолитовый шов также претерпел более поздние разрывные нарушения. Самыми отчетливыми из них являются позднегерцинские левые сдвиги, секущие под различными углами структуры южного крыла шовной зоны и, возможно, связанные с касательной континентальной субдукцией, которая восточнее, в китайском Тянь-Шане, привела к полному выклиниванию герцинид Южного Тянь-Шаня. Более детально геологическое строение Кокшаальского сегмента этого региона описано в ряде 
публикаций (см.: [Поршняков, 1960; 1961; 1968; 1983; Яговкин, 1969; 1973; Довжиков, 1977; Бискэ и др., 1985; Брежнев, 1976; 1981; 1994; Христов, 1981; 1989; 1990; и др.]), включая фундаментальные монографии [Поршняков, 1973; Бискэ, 1996].

В отличие от расположенных западнее Кызылкумского и Алайского сегментов Южного Тянь-Шаня, где гранитоидный магматизм проявлен весьма широко и представлен разнообразными типами гранитоидов с явным преобладанием известково-щелочных серий, Кокшаальский сегмент отличается относительно меньшим распространением магматических пород на современном эрозионном срезе и преимущественным развитием раннепермских постколлизионных гранитоидов субщелочной серии в ассоциации с небольшими объемами щелочных пород [Konopelko et al., 2007; 2009]. Так как интрузии Кокшаальского комплекса демонстрируют секущие взаимоотношения со всеми верхнепалеозойскими осадочными формациями региона и в основном не затронуты герцинскими деформациями, они традиционно рассматриваются в геологической литературе как постколлизионные [Соломович, Трифонов, 1989; 1990; Solomovich, Trifonov, 2002]. Среди исследований по магматизму Кокшаала можно отметить труды, в рамках которых в единый региональный Кокшаальский комплекс были выделены субщелочные гранитоиды [Стратифицированные..., 1982], а также те работы, где было указано на их сходство с гранитами рапакиви [Соломович, Трифонов, 1989; 1990; Solomovich, 2007].

Гранитоидами Кокшаальского комплекса, которые являются главным объектом исследования автора, сформированы более 20 массивов (рис. 2.3) и подразделяются на три подкомплекса (Джангартский, Учкошконский и Иныльчекский), различных по составу, геохимической и металлогенической специализации и уровню глубинности [Геология и полезные ископаемые..., 1954; Геологическое строение..., 1966; 1967; Магматизм..., 1976; Стратифицированные..., 1982; Геологическая съемка..., 1985; Solomovich, 2007]. Асcоциирующие с гранитоидами щелочные породы описаны как региональный Суртекинский комплекс [Буров и др., 1965; Стратифицированные..., 1982]. Некоторые интрузии Кокшаальского комплекса расположены в непосредственной близости от Атбаши-Иныльчекского разлома, в зоне которого размещаются массивы гранитоидов известково-щелочной серии (І-типа) (рис. 2.2, 2.3), описанные в составе Уланского и Теректинского комплексов [Богдецкий, 1983; 1987; Стратифицированные..., 1982], которые также были нами изучены. На региональных геологических картах интрузии Кокшаальского комплекса обычно показываются как раннепермские, интрузии Суртекинского комплекса - как ранне- или среднепермские, а массивы Уланского и Теректинского комплексов - как средне- или позднекарбоновые (см.: [Геологическая карта Кыргызской ССР, 2008]).

Поскольку массивы Джангартского и Учкошконского подкомплексов близки по составу, их геохимические особенности и петрогенезис рассматри- 


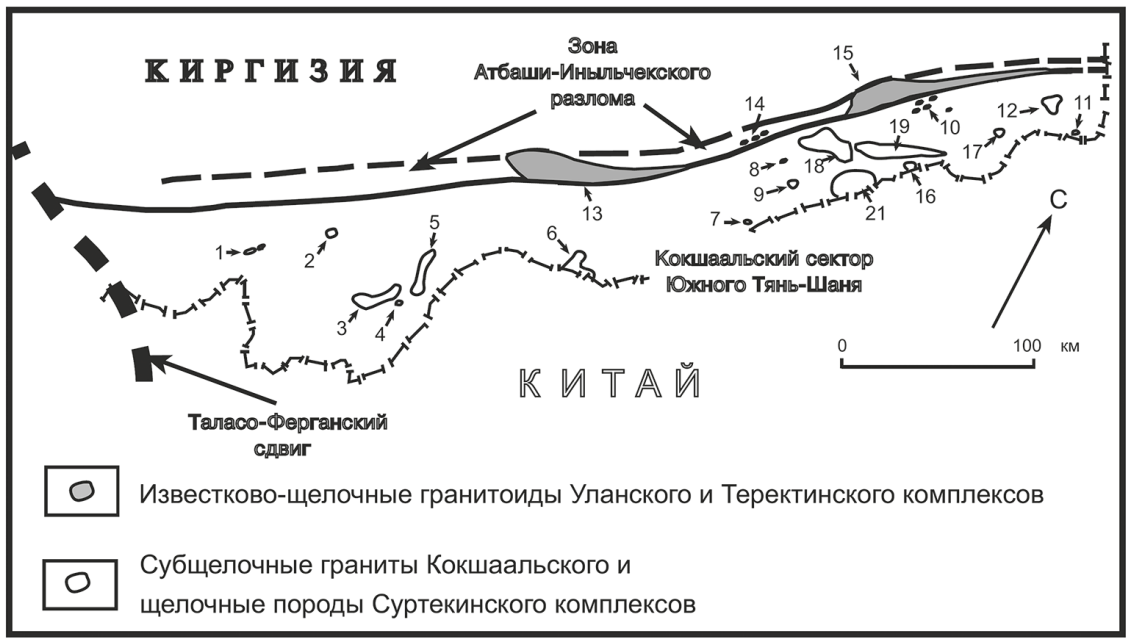

Puc. 2.3. Размещение массивов гранитоидов в пределах Кокшаальского сегмента Южного Тянь-Шаня:

1 - Шырыктинский, 2 - Суртекинский, 3 - Коккиинский, 4 - Караторский,

5 - Мудрюмский, 6 - пик Данкова, 7 - Карабельский, 8 - Акташский,

9 - Пикертыкский и Сарыбулакский, 10 - Иныльческий, Ташкоринский,

Суходольский, Майдаадырский и Атджайляуский, 11 - пик Победы,

12 - Комсомольский, 13 - Уланский, 14 - Бешмойнокские тела, 15 - Теректинский,

16 - Джеткайский, 17 - Майбашский и Айрансуйский, 18 - Учкошконский,

19 - Акшийракский, 20 - Кайчинский, 21 - Джангартский, 22 - Айлагырский

ваются вместе в $\$ 2.2$. Так как гранитоиды этих подкомплексов тесно ассоциируют с сиенитами и карбонатитами Суртекинского комплекса, в $\$ 2.2$ также приводится краткое описание щелочных интрузий, хотя последние не являются главным объектом исследования в настоящей работе.

Малые интрузии Иныльчекского подкомплекса, расположенные в западной части Кокшаальского сегмента (см. рис. 2.2) и сложенные дифференцированными литий-фтористыми гранитами, рассматриваются отдельно в $\$ 2.3$. Поскольку некоторые интрузии Иныльчекского подкомплекса находятся в непосредственной близости от распложенного в зоне Атбаши-Иныльчекского разлома одновозрастного Теректинского массива известково-щелочных гранитоидов, в $\$ 2.3$ также дается сравнительная характеристика Иныльчекского и Теректинского комплексов и рассматривается возможный сценарий их образования. Наконец, в последнем разделе этой главы сформулированы общие выводы о петрогенезисе, источниках и обстановке формирования гранитоидов Кокшаальского сегмента Южного Тянь-Шаня. 


\section{§ 2.2. Субщелочные гранитоиды центральной части Кокшаальского сегмента}

Более 15 массивов в центральной части Кокшаальского сегмента сложены субщелочными гранитоидами (см. рис. 2.2, 2.3). Наиболее крупные (Джангартский, Акшийракский, Учкошконский, Мудрюмский, Коккиинский площадью более 150-200 км² каждый) имеют форму удлиненную или близкую к изометричной. Форма мелких интрузий более сложная, часто встречаются многочисленные апофизы причудливой формы. Контакты интрузивные, ровные, секущие слоистость вмещающих пород. В экзозонах Джангартского и Акшийракского массивов проявлены полевошпат-пироксеновые и биотитовые роговики и скарны. Учкошконский, Мудрюмский и Коккиинский массивы, а также многочисленные мелкие интрузии характеризуются значительно меньшей степенью экзоконтактовых изменений. В то же время они часто сопровождаются скарнами (Сарыбулакский массив) и оловоносными грейзенами (Учкошконский массив). Состав пород варьирует от кварцевых монцонитов до амфибол-биотитовых гранитов и биотитовых лейкогранитов. В геологической литературе амфиболсодержащие гранитоиды описаны как Джангартский подкомплекс, а лейкограниты - как Учкошконский подкомплекс Кокшаальского регионального комплекса [Стратифицированные..., 1982]. Геологические особенности и минеральный состав пород Джангартского и Учкошконского подкомплексов, а также ассоциирующие с ними щелочные интрузии Суртекинского комплекса представлены ниже отдельно в соответствии с традициями описания магматических комплексов, принятыми в публикациях по геологии этого региона [Додонова, 1974; Стратифицированные..., 1982]. Однако так как породы обоих гранитоидных подкомплексов встречаются в пределах одних и тех же массивов и формируют непрерывный тренд составов, они рассматриваются в качестве единой магматической серии в разделах, посвященных геохимии и петрогенезису этих пород.

Джангартский подкомплекс Кокшаальского комплекса. К первой фазе относятся кварцевые амфибол-биотитовые монцониты, изученные в Акташском массиве и слагающие небольшое тело в пределах Акшийракского массива. Субщелочные габброиды и монцонитоиды слагают также два самостоятельных массива: Карабельский и Караторский. Минеральный состав кварцевых монцонитов Акташского массива: олигоклаз (35\%), калишпат (30\%), кварц $(10 \%)$, амфибол (10\%), биотит (5-7\%). Акцессории: магнетит, апатит, сфен, циркон, ортит. Джангартский и Акшийракский массивы сложены в основном крупнозернистыми биотит-амфиболовыми гранитами и граносиенитами со структурой рапакиви, относимыми ко второй фазе (рис. 2.4, 2.5). В качестве фациальной разновидности выделены порфировидные трахитоидные биотитовые граниты юго-восточной части Джангартского массива. На диаграмме Штрекайзена овоидные граносиениты Джангартского и Акшийракского массивов 
попадают на границу полей кварцевого монцонита и адамеллита. Их средний минеральный состав: олигоклаз (30-35\%), максимальный микроклин (35\%), кварц (15-25\%), амфибол (5-7 \%), биотит (3-5\%). Акцессории: апатит, циркон, флюорит, ортит, магнетит. Металлогеническая специализация граносиенитов определяется связанными с ними месторождениями золото-арсенопиритовой формации [Mao et al., 2004].

Уикошконский подкомплекс Кокиаальского комплекса. Лейкограниты Учкошконского подкомплекса слагают крупный одноименный массив, а также

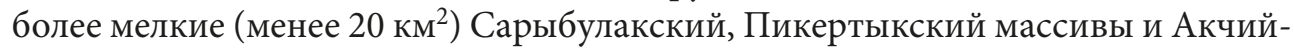
ский шток, прорывающий западную часть Акшийракского массива. К Учкошконскому подкомплексу также относятся многочисленные жилы биотитовых гранитов в Джангартском и Акшийракском массивах и некоторые интрузии к югу и востоку от последнего. Мудрюмская и Коккиинская интрузии, сопоставимые по размерам с Учкошконским массивом, расположены в западной части Кокшаальского сектора и также рассматриваются в составе Учкошконского подкомплекса, несмотря на определенные вещественные и геохимические особенности.

Учкошконский подкомплекс сложен тремя разновидностями пород, между которыми описаны как интрузивные контакты, так и постепенные переходы. Главными по объему являются крупнозернистые равномернозернистые биотитовые (в Мудрюмском и Сарыбулакском массивах местами биотит-амфиболовые) лейкограниты. Среди крупнозернистых гранитов встречаются участки резко порфировидных мелко- и среднезернистых биотитовых гранитов с редкими (менее $50 \%$ ) крупными (1-2 см) вкрапленниками калишпата. Более поздними являются миароловые биотитовые гранит-порфиры, кварцевые порфиры с кокардами турмалина. Этот набор пород является чрезвычайно устойчивым и повторяется практически во всех массивах независимо от их размеров. Особняком стоят амфиболсодержащие граниты Акчийского штока и Коккиинский массив, сложенный очень своеобразными крупнозернистыми миароловыми амфибол-биотитовыми лейкогранитами. Минеральный состав крупнозернистых гранитов Учкошконского массива: олигоклаз (25\%), калиевый полевой шпат (35\%), кварц (30-33\%), биотит (2-5\%). Акцессории: магнетит, апатит, циркон, мусковит, турмалин, флюорит. Миароловые лейкогранит-порфиры отличаются повышенным содержанием кварца (35-40 \%) и еще более сильным преобладанием калишпата над плагиоклазом (40 и $20 \%$, соответственно). Среди акцессорных фаз иногда появляются топаз и касситерит. Появление амфиболсодержащих гранитов в Мудрюмском и Сарыбулакском массивах, вероятно, связано с усвоением материала карбонатных пород, с которыми контактируют эти интрузии. Для некоторых интрузий характерны ксенолиты субщелочных диоритоидов (Сарыбулакский массив). Дайковый комплекс представлен турмалиновыми кварцевыми порфирами, онгориолитами. Следует также отметить чрезвычайно интересные дайки кварцевых 


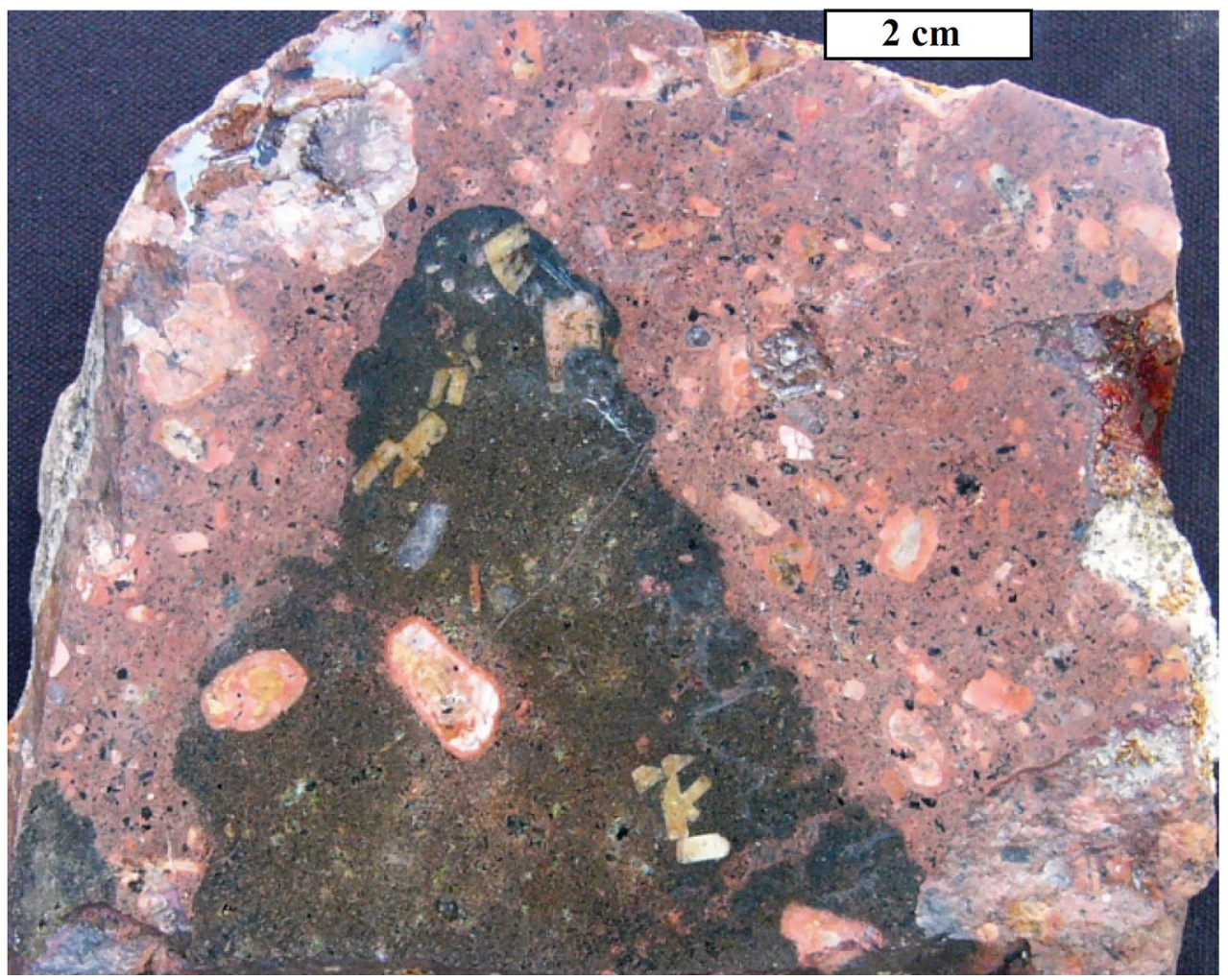

Puc. 2.4. Мафические включения в гранитоидном матриксе. Мудрюмский массив

диорит- и монцонит-порфиров, секущие Мудрюмский и Коккиинский массивы. Ряд особенностей - неравновесные минеральные ассоциации, наличие резорбированных вкрапленников кварца и плагиоклаза - говорит в пользу гибридного происхождения этих пород в результате смешения сосуществующих основных и кислых магм. Фотография мафического базальтоидного включения в составной дайке в Мудрюмском массиве с признаками минглинга показана на рис. 2.4. Фотографии образцов, иллюстрирующие текстуры главных типов пород Кокшаальского комплекса, включая овоидные граниты рапакиви, равномернозернистые и турмалинсодержащие миароловые лейкограниты, приведены на рис. 2.5. Детальное петраграфическое описание этих типов пород было опубликовано Соломовичем и Трифоновым [Solomovich, Trifonov, 2002]. Лейкограниты Учкошконского подкомплекса характеризуются отчетливой геохимической специализацией на олово. С ними связано несколько месторождений олова и полиметаллов, наиболее крупные из которых - Учкошконское и Сарыбулакское - относятся к касситерит-сульфидной формации [Геология оловорудных..., 1977; Соломович, Трифонов, 1989; 1990; Трифонов, Соломович, 1993; Павловский и др., 1998; 2010]. 

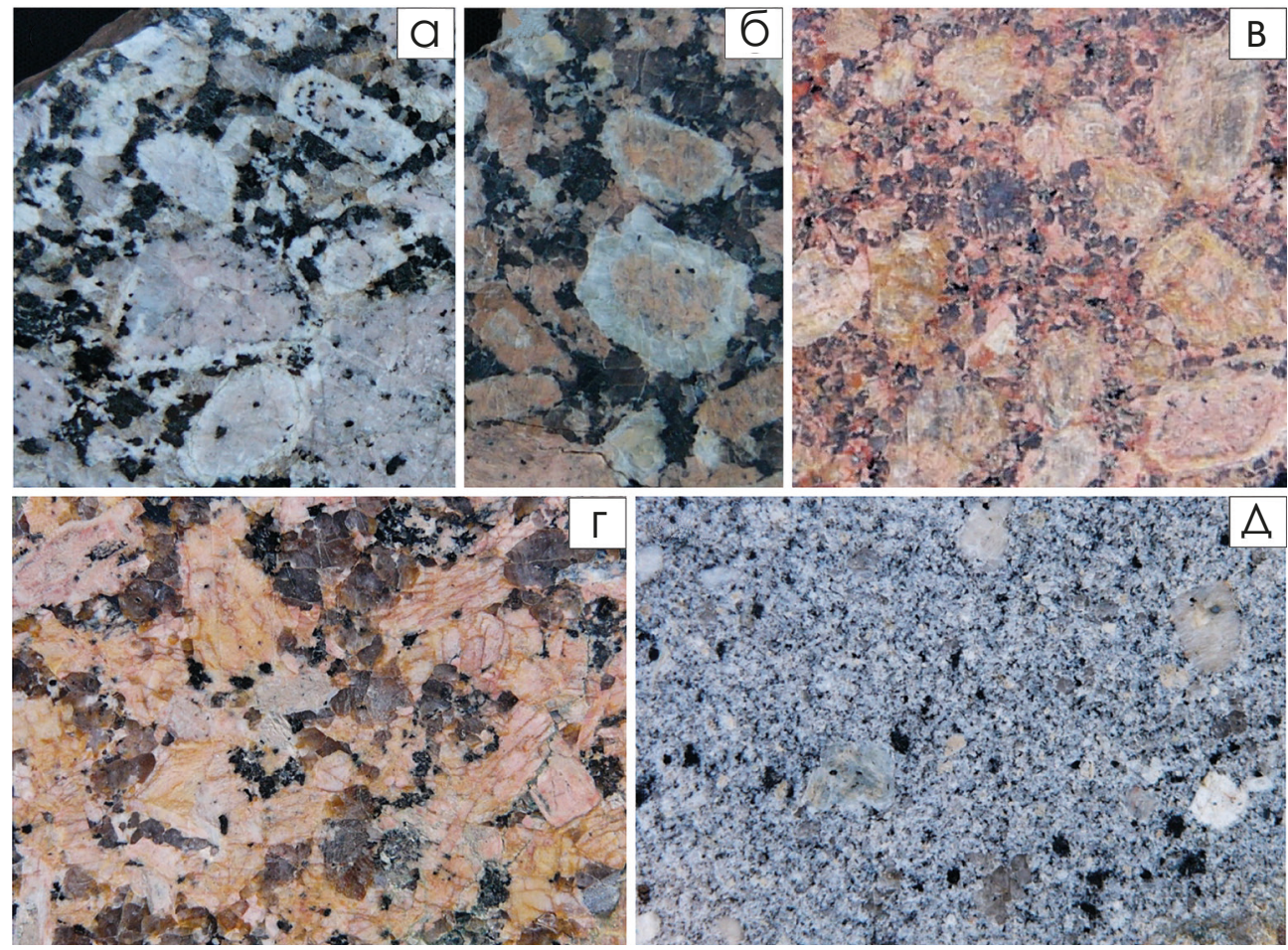

Puc. 2.5. Главные типы гранитоидов Кокшаальского комплекса (Джангартский и Учкошконский подкомплексы):

a, 6 - овоидные граниты рапакиви Джангартского массива, размер по горизонтали 6 и 4 см соответственно; в - лейкогранит Коккиинской интрузии с овоидами калишпата без плагиоклазовых отторочек (питерлит), размер - 4 см; г - равномернозернистый лейкогранит Учкошконского массива, размер - 7 см; д - турмалинсодержащий миароловый гранит мудрюмского массива, размер - 7 см

Суртекинский комплекс. Суртекинский комплекс щелочных и щелочноземельных сиенитов и карбонатитов включает несколько небольших и средних массивов, сосредоточенных (за исключением Суртекинского массива) в восточной части Кокшаальского сектора. Суртекинский массив обнажен на площади 20 км²$^{2}$ расположен на южном склоне Атбашинского хребта и в структурном плане тяготеет к западной группе интрузий, в которую входят Мудрюмский и Акшийракский массивы. Он представляет собой кольцевую интрузию, сложенную шонкинитами, щелочными сиенитами, нефелиновыми сиенитами (главная по объему фаза), кварцевыми сиенитами [Додонова, 1974; Стратифицированные..., 1982; Соломович, Трифонов, 1989; 1990; Бискэ и др., 1996]. Кайчинский, Айлагырский, Куюкапский массивы, а также Сарысайский карбонатитовый шток и нерасчлененный щелочной массив пика Победы расположены к югу и востоку от Учкошконского рудного узла, причем первые два непосредственно в пределах Джангартского массива. В интрузиях восточной 
части Кокшаальского сектора преобладают щелочные сиениты. В Джангартском массиве тела щелочных сиенитов окаймлены мощными зонами (первые сотни метров) пород гибридного состава. Подобные же породы (мелко- и среднезернистые амфиболовые кварцевые сиениты) отмечены среди овоидных граносиенитов Акшийракского массива. Постепенные переходы между граносиенитами Джангартского подкомплекса и породами щелочного ряда, наличие явно неравновесных минеральных ассоциаций, по-видимому, объясняются смешением магм разного состава и свидетельствуют о субсинхронности формирования щелочной и субщелочной серий. С Сарысайским карбонатитовым штоком связано рудопроявление тантало-ниобатов [Соломович, Трифонов, 1989; 1990; Трифонов, Соломович, 1993; Павловский и др., 1998; 2010].

\subsection{1. Геохимия}

Результаты химических анализов главных типов магматических пород Джангартского и Учкошконского подкомплексов Кокшаальского комплекса приведены в Приложении Б.1. Концентрации петрогенных и редких элементов определены в лаборатораториях Горного университета Сент-Этьена (École des Mines de Saint-Étienne, Франция) и Потсдамском центре наук о Земле (GFZ, Германия), а содержания F и В - в лаборатории Actlabs (Канада); аналитические методы описаны нами ранеe [Konopelko et al., 2007].

Биотит-амфиболовые граниты и кварцевые монцониты (граносиениты со структурой рапакиви) Джангартского и Акшийракского массивов характеризуются содержаниями $\mathrm{SiO}_{2}$ в диапазоне 64-68 вес. \%. Это умеренно глиноземистые породы $\left(\mathrm{ASI}=\mathrm{Al}_{2} \mathrm{O}_{3} /\left(\mathrm{CaO}+\mathrm{Na}_{2} \mathrm{O}+\mathrm{K}_{2} \mathrm{O}\right)\right.$ мол. $\left.0,87-0,93\right)$, которые отличаются высоким содержанием щелочей $\left(\mathrm{Na}_{2} \mathrm{O}+\mathrm{K}_{2} \mathrm{O}\right.$ от 7,5 до 10,5 вес. \% при $\mathrm{K}_{2} \mathrm{O} /$ $\left.\mathrm{Na}_{2} \mathrm{O} 1,5-1,0\right)$, резко обогащены железом по отношению к магнию ( $\mathrm{Fe} /(\mathrm{Fe}+\mathrm{Mg})$ от 0,77 до 0,95$)$ и соответственно попадают в поля щелочной и щелочно-известковой серий на диаграмме $\left(\mathrm{Na}_{2} \mathrm{O}+\mathrm{K}_{2} \mathrm{O}-\mathrm{CaO}\right)$ vs. $\mathrm{SiO}_{2}$ (рис. 2.6а) и в поле пород толеитовой серии на диаграмме $\mathrm{FeO}^{\mathrm{tot}} /\left(\mathrm{MgO} \mathrm{FeO}^{\text {tot }}\right)$ vs. $\mathrm{SiO}_{2}$ (рис. 2.66; Приложение Б.1). Породы характеризуются повышенными содержаниями U, Th, Nb, Ta, Y, Zr, Hf, LREE и F. Спектры распределения REE умеренно фракционированы с незначительным обогащением легкими REE и небольшими отрицательными Eu аномалиями (рис. 2.7). Спектры распределения концентраций редких элементов, представленные на мультикатионных диаграммах (см. рис. 2.7), демонстрируют обогащение литофильными элементами и отчетливые отрицательные аномалии $\mathrm{Ba}, \mathrm{Sr}, \mathrm{P}$ и Ti, а также несколько менее выраженные отрицательные аномалии $\mathrm{Nb}$ и Та.

Содержания $\mathrm{SiO}_{2}$ в лейкогранитах варьируют в диапазоне 69-75 вес. \%. Эти породы также отличаются калиевой специализацией $\left(\mathrm{Na}_{2} \mathrm{O}+\mathrm{K}_{2} \mathrm{O} 7,8-\right.$ 9,0 вес. \% и $\left.\mathrm{K}_{2} \mathrm{O} / \mathrm{Na}_{2} \mathrm{O} 1,2-2,1\right)$ и в основном попадают в поле щелочно-извест- 


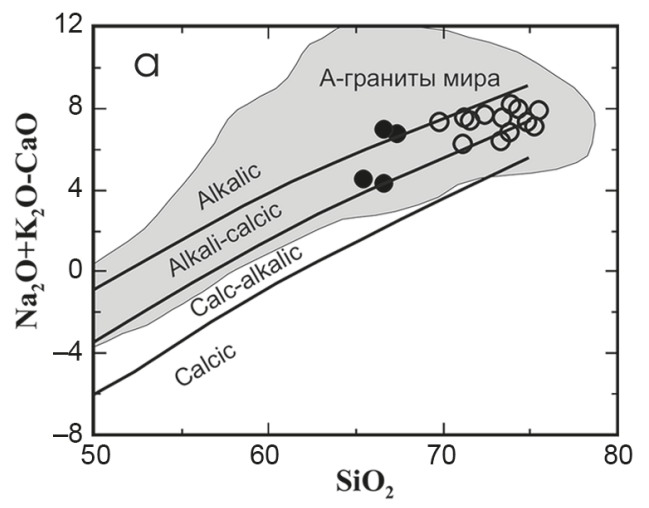

- Биотит-амфиболовые граниты

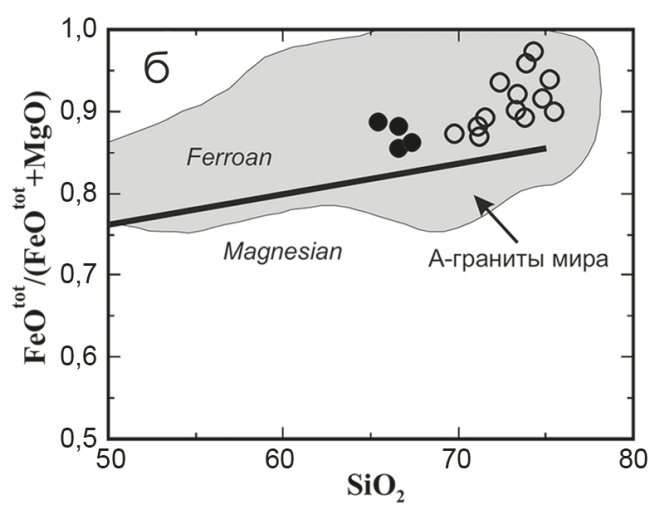

О Лейкограниты

Рис. 2.6. Химические составы гранитоидов Кокшаальского комплекса на классификационных диаграммах: a - ( $\left.\mathrm{Na}_{2} \mathrm{O}+\mathrm{K}_{2} \mathrm{O}-\mathrm{CaO}\right)$ vs. $\mathrm{SiO}_{2}$, вес. \%; $6-\mathrm{FeO} /\left(\mathrm{FeO}^{\text {tot }}+\mathrm{MgO}\right)$ vs. $\mathrm{SiO}_{2}$, вес. \%, поля по [Frost et al., 2001]

ковой серий на диаграмме $\left(\mathrm{Na}_{2} \mathrm{O}+\mathrm{K}_{2} \mathrm{O}-\mathrm{CaO}\right)$ vs. $\mathrm{SiO}_{2}$ (см. рис. 2.6а, Приложение Б.1). Они характеризуются умеренно глиноземистыми составами или слабо пересыщены глиноземом (ASI 0,92-1,16, см. Приложение Б.1). Лейкограниты обеднены Са и резко обогащены железом по отношению к магнию $(\mathrm{Fe} /(\mathrm{Fe}+\mathrm{Mg})$ от 0,8 до 0,95 , см. рис. $2.66,2.8)$. Они характеризуются пониженными содержаниями $\mathrm{Ba}$ и $\mathrm{Sr}$, и высокими концентрациями $\mathrm{Rb}$ и высокозарядных катионов, что определяет правый наклон спектров распределения редких элементов на мультикатионных диаграммах с отчетливыми отрицательными аномалиями $\mathrm{Sr}, \mathrm{P}$ и $\mathrm{Ti}$ (см. рис. 2.7). Повышенные содержания Li (от 50 до 200 ppm) и F (до 0,61 вес.\%) обусловлены присутствием в их составе литиевых слюд и в некоторых случаях топаза. Концентрации бора, определенные в пяти пробах, варьируют от 20 до 40 ppm. Повышенные содержания Sn в лейкогранитах (6-68 ppm) подчеркивают их геохимическую специализацию на олово (см. Приложение Б.1). Спектры распределения REE в лейкогранитах слабо фракционированы с незначительным обогащением легкими REE и характеризуются резкими отрицательными Еu аномалиями (см. рис. 2.7). Характерными чертами являются уменьшение содержаний легких REE, увеличение содержаний тяжелых REE и резко выраженные отрицательные аномалии $\mathrm{Eu}$ в наиболее дифференцированных разновидностях лейкогранитов.

Мафические разновидности пород, ассоциирующие с кокшаальскими гранитами, обычно встречаются в виде небольших включений в гранитах. Составная дайка протяженностью 1000 м и мощностью 50 м с признаками одновременного внедрения основного и кислого расплава была задокументирована в Мудрюмском массиве (см. рис. 2.4). Основные породы этой дайки (пр. 280401) соответствуют толеитовому габбро с относительно низким содержанием 

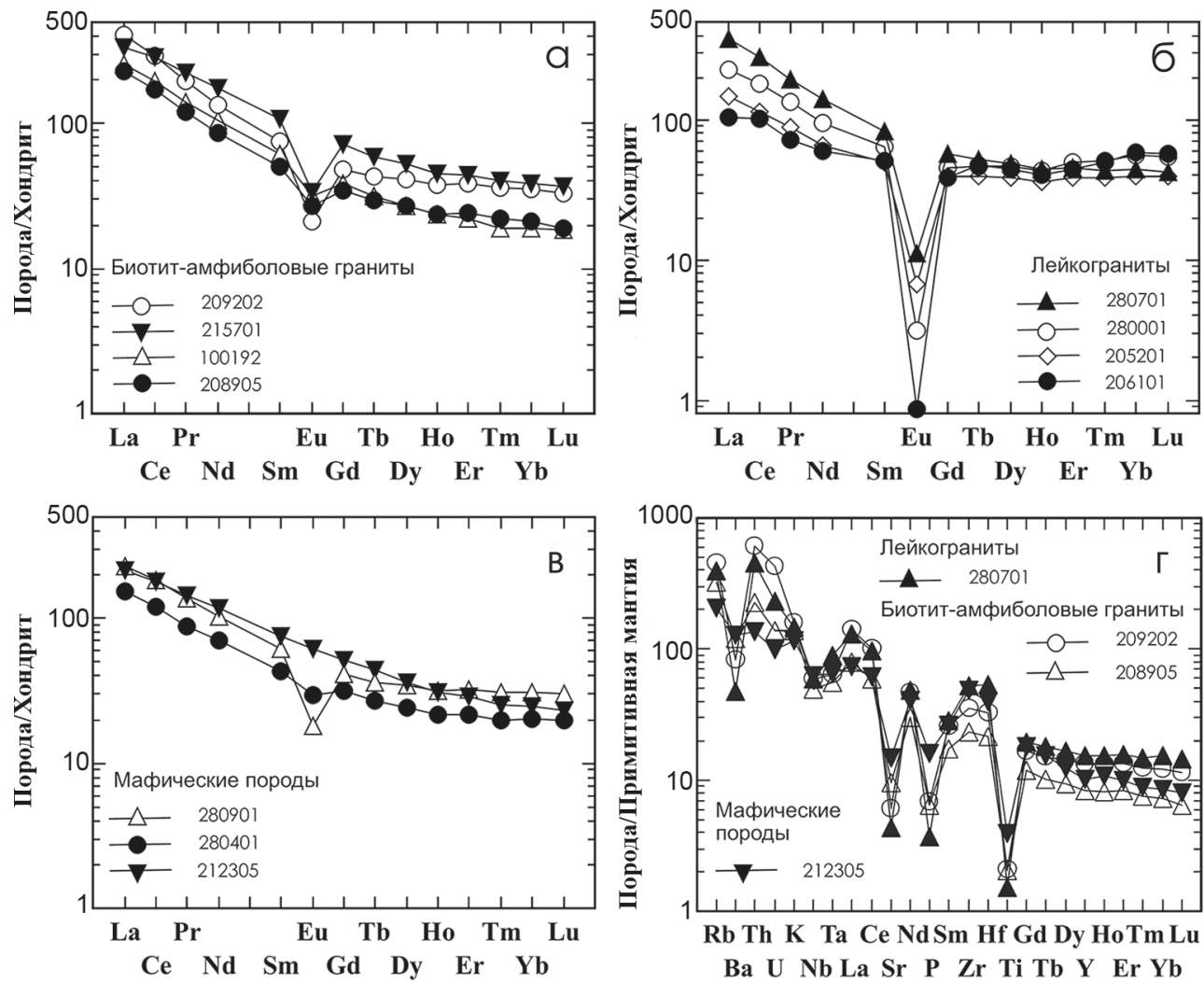

PUс. 2.7. Спектры распределения концентраций REE в магматических породах Кокшаальского комплекса, нормированные к хондриту:

а - биотит-амфиболовые граниты; 6 - лейкограниты; в - мафические породы; г - спектры распределения концентраций редких элементов, нормированные к примитивной мантии. Для нормирования использовались значения концентраций по [Sun, McDonough, 1989]

$\mathrm{Al}_{2} \mathrm{O}_{3}(14,5 \%)$, высоким содержанием $\mathrm{Fe} /(\mathrm{Fe}+\mathrm{Mg})\left(0,62 \%\right.$ при $\left.56 \% \mathrm{SiO}_{2}\right)$ и повышенным содержанием $\mathrm{TiO}_{2}(1,8 \%)$ (см. Приложение Б.1). Крупнозернистый монцодиорит (пр. 212305) из интрузии Акташ имеет сходный состав (см. Приложение Б.1). Обе породы проецируются в поле толеитовой серии на диаграмме AFM и в поля внутриплитных базальтов на дискриминационных диаграммах. Спектры распределения REE в мафитах слабо фракционированы и характеризуются отсутствием или незначительными отрицательными Еu аномалиями (см. рис. 2.7). Спектры распределения концентраций редких элементов, представленные на мультикатионных диаграммах (см. рис. 2.7), демонстрируют умеренное обогащение литофильными элементами и отсутствие отчетливых отрицательных аномалий $\mathrm{Nb}$ и Та.

Обе разновидности гранитов Кокшаальского комплекса отличаются весьма высокими отношениями $\mathrm{Fe} / \mathrm{Mg}$ и умеренно глиноземистыми составами, 

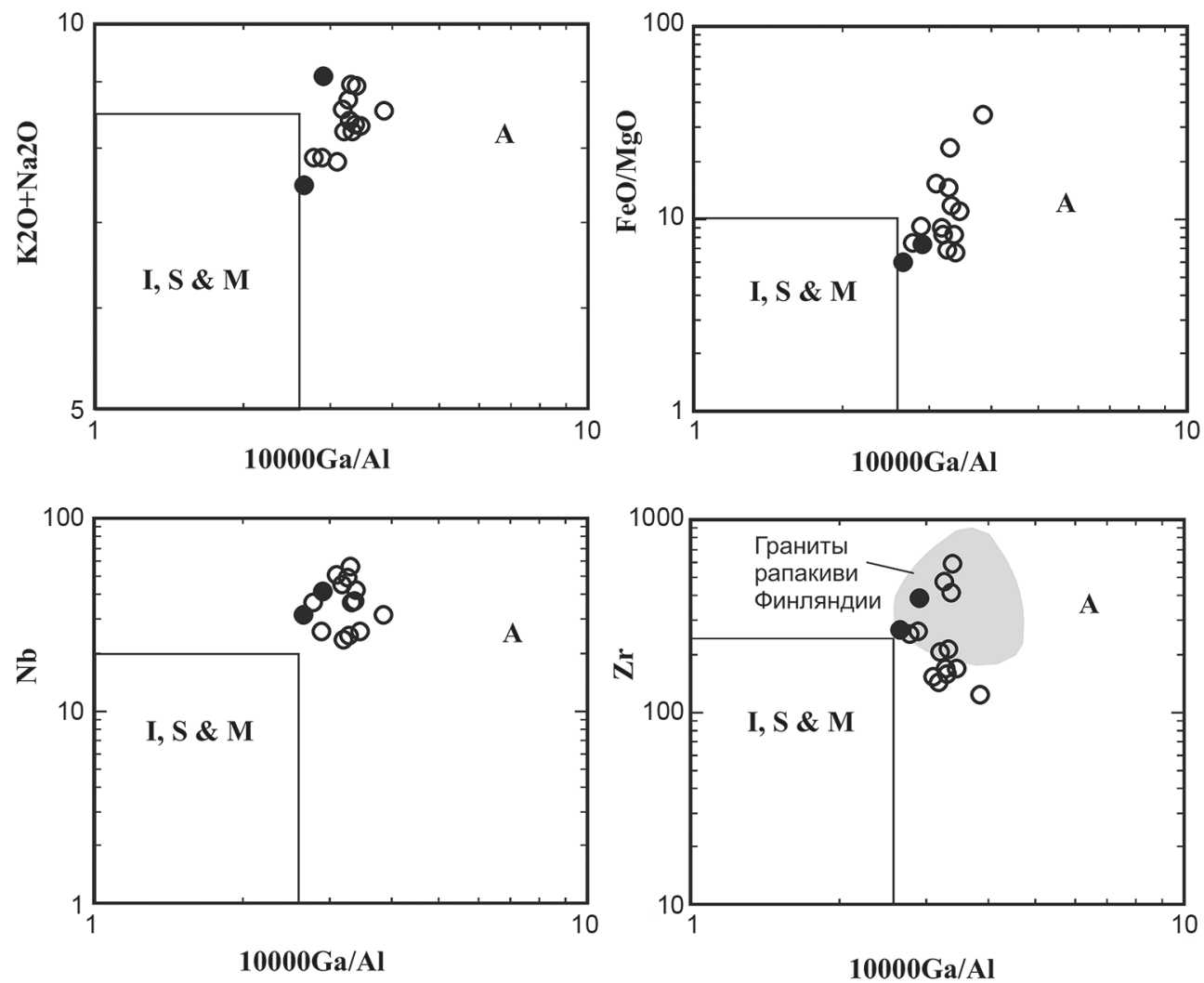

Puc. 2.8. Дискриминационные диаграммы [Whalen et al., 1987] $\mathrm{K}_{2} \mathrm{O}+\mathrm{Na}_{2} \mathrm{O}$, FeO/MgO, $\mathrm{Nb}$ и $\mathrm{Zr}$ vs. $10000 * \mathrm{Ga} / \mathrm{Al}$, иллюстрирующие принадлежность кокшаальских гранитов к А-типу. Для сравнения на диаграмме Zr vs. $10000 * \mathrm{Ga} / \mathrm{Al}$ показано поле составов гранитов рапакиви Финляндии, по [Haapala et al., 2005]

что указывает на их сходство с гранитами А-типа. Повышенные отношения $\mathrm{Fe} / \mathrm{Mg}$ являются одним из важнейших признаков А-гранитов. На диаграмме $\mathrm{FeO}^{\text {tot }} /\left(\mathrm{FeO}^{\text {tot }}+\mathrm{MgO}\right)$ vs. вес. \% $\mathrm{SiO}_{2}$ (см. рис. 2.66) составы гранитов Кокшаала проецируются в поле средних составов А-гранитов мира [Frost et al., 2001]. По редкоэлементному составу граниты Кокшаальского комплекса также соответствуют гранитам А-типа. Они содержат большие концентрации высокозарядных катионов и проецируются в поля внутриплитных гранитов на дискриминационных диаграммах. Кроме этого граниты Кокшаала также характеризуются повышенными отношениями $10000^{\star} \mathrm{Ga} / \mathrm{Al}$, что также является типичным для А-гранитов (см. рис. 2.8, Приложение Б.1). 


\subsection{2. Изотопный состав $\mathrm{Nd}$ в породах}

Изотопный состав $\mathrm{Nd}$ был проанализирован в восьми пробах гранитов и двух пробах мафических пород Кокшаальского комплекса. Для сравнения были также проанализированы три пробы ордовикских гранитов из Срединного и Северного Тянь-Шаня и гнейс Кочкорки из Северного Тянь-Шаня с возрастом $1050 \pm 20$ млн лет [Киселев, 1999]. Анализ изотопного состава $\mathrm{Nd}$ в валовых пробах выполнен на масс-спектрометре Finnigan в Институте геологии и геохронологии докембрия РАН в Санкт-Петербурге. Детали аналитической процедуры опубликованы нами ранее [Konopelko et al., 2007]. Результаты представлены в Приложении В.1 и на диаграмме, показанной на рис. 2.9.

Магматические породы Кокшаала характеризуются относительно небольшим разбросом значений отношений ${ }^{147} \mathrm{Sm} /{ }^{144} \mathrm{Nd} \quad(0,1089-0,1286)$ и ${ }^{143} \mathrm{Nd} /{ }^{144} \mathrm{Nd}(0,512127-0,512506)$ за исключением пробы дифференцированного кварцевого порфира (пр. 206101). Породы Срединного и Северного

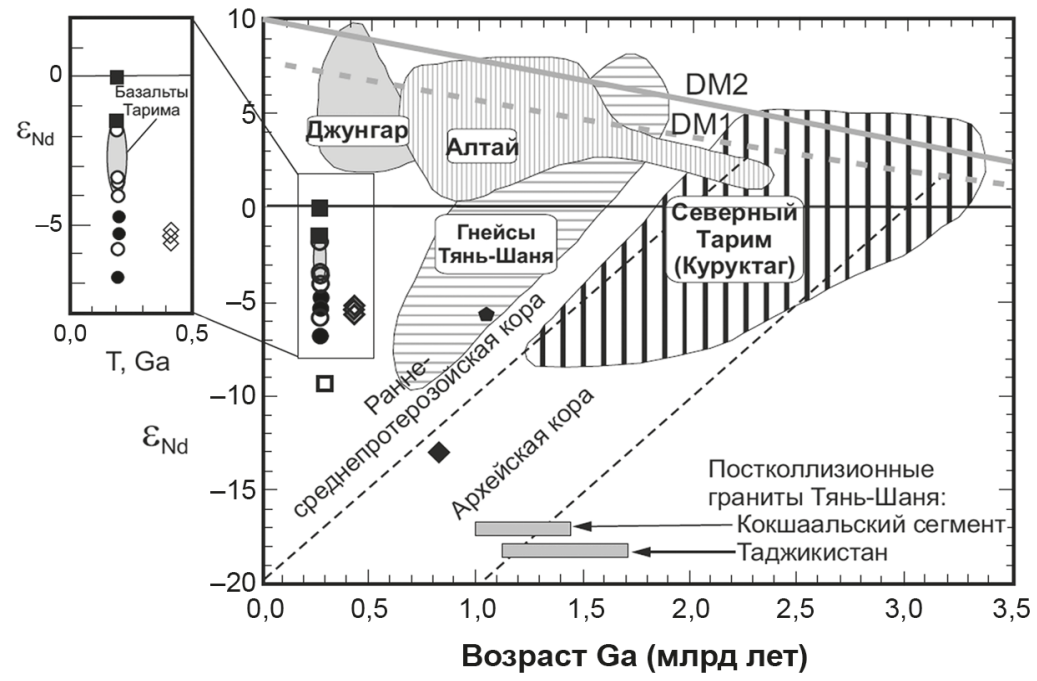

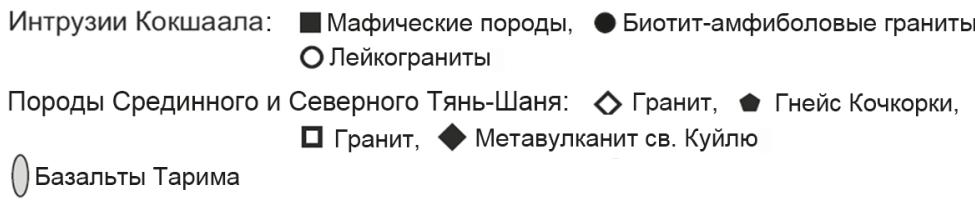

Puc. 2.9. Изотопные составы Nd в гранитоидах Кокшаальского сегмента на диаграмме عNd vs. возраст кристаллизации с данными по сопредельным террейнам Джунгара, Алтая и Тарима, по [Hu et al., 2000; Jiang et al., 2004; Jahn et al., 2000]. Диапазон модельных возрастов гранитоидов Кокшаальского сегмента обозначен вдоль горизонтальной оси, где для сравнения также показаны модельные возрасты гранитов соседних районов таджикского Тянь-Шаня, по [Konopelko et al., 2015; 2017]. DM1 - модель [De Paolo, 1981]; DM2 - модель [Jahn et al., 2000] 
Тянь-Шаня характеризуются более широким разбросом значений ${ }^{147} \mathrm{Sm} /{ }^{144} \mathrm{Nd}$ $(0,0778-0,12559)$ и ${ }^{143} \mathrm{Nd} /{ }^{144} \mathrm{Nd}(0,511808-0,512159)$. Все проанализированные породы имеют отрицательные значения $\varepsilon N d t$. Кварцевый монцонит из массива Акташ отличается наиболее высоким значением $\varepsilon \mathrm{Ndt}$ около 0. Значения $\varepsilon N d t$ в трех пробах амфибол-биотитовых гранитов из Джангартского и Акшийракского массивов варьируют от $-6,8$ до $-4,8$. Пять проб лейкогранитов Учкошконского, Коккиинского, Мудрюмского и Акташского массивов характеризуются большим разбросом значений $\varepsilon \mathrm{Ndt}$ от $-5,9$ до $-1,6$.

Значения $\varepsilon N d t$ в трех пробах ордовикских гранитов и в неопротерозойском гнейсе варьируют от $-5,6$ до -4,9. Отрицательные значения $\varepsilon N d t$ в гранитоидах Кокшаала указывают на их происхождение из раннемезопротерозойских коровых источников, что подтверждается их модельными возрастами $\mathrm{T}_{\mathrm{DM}}$ в интервале 1,05-1,43 млрд лет, рассчитанными по модели [De Paolo, 1981]. Это также справедливо для ордовикских гранитов.

\subsection{3. Результаты U-Pb датирования цирконов}

Возраст четырех пород Кокшаальского комплекса был определен с помощью $\mathrm{U}-\mathrm{Pb}$ датирования цирконов in situ. Выбранные для датирования породы включали биотит-амфиболовый гранит со структурой рапакиви из интрузии Джангарт (пр. 209202), биотитовый лейкогранит из Учкошконского массива (пр. 206801), биотитовый лейкогранит из Мудрюмского массива (пр. 280001) и биотит-амфиболовый лейкогранит из Коккиинского массива (пр. 280701). Анализ U-Th-Pb изотопного состава цирконов был выполнен с помощью ионного микрозонда Cameca IMS 1270 в лаборатории NORDSIM Шведского музея естественной истории в Стокгольме. Детали аналитической процедуры были опубликованы нами ранеe [Konopelko et al., 2007]. Аналитические результаты и диаграммы с конкордией [Tera, Wasserburg, 1973; 1974] представлены в Приложении В.2 и на рис. 2.10. Расчет возрастов производился с помощью программы Isoplot/Ex v. 2.05 [Ludwig, 1999]. Цирконы, выделенные из четырех проб, представлены достаточно однородными, хорошо ограненными прозрачными или желтовато-коричневыми призматическими зернами с типичной магматической зональностью на катодолюминесцентных изображениях. Для датирования были выбраны удлиненные зерна цирконов размером 200-400 микрон.

Изотопные составы всех проанализированных зерен проецируются на линию конкордии или вблизи нее. Средневзвешенный ${ }^{206} \mathrm{~Pb} /{ }^{238} \mathrm{U}$ возраст $295 \pm 4$ млн лет $($ СКВО $=0,32)$ вычислен на основании 11 анализов зерен циркона из Джангартского массива. Если три слабо дискордантных анализа исключить из расчетов, то восемь оставшихся позволяют определить конкордантный возраст $296 \pm 4$ млн лет $($ СКВО $=0,69)$. Пять анализов зерен циркона из Учкошконского массива дают возможность подсчитать средневзвешенный 

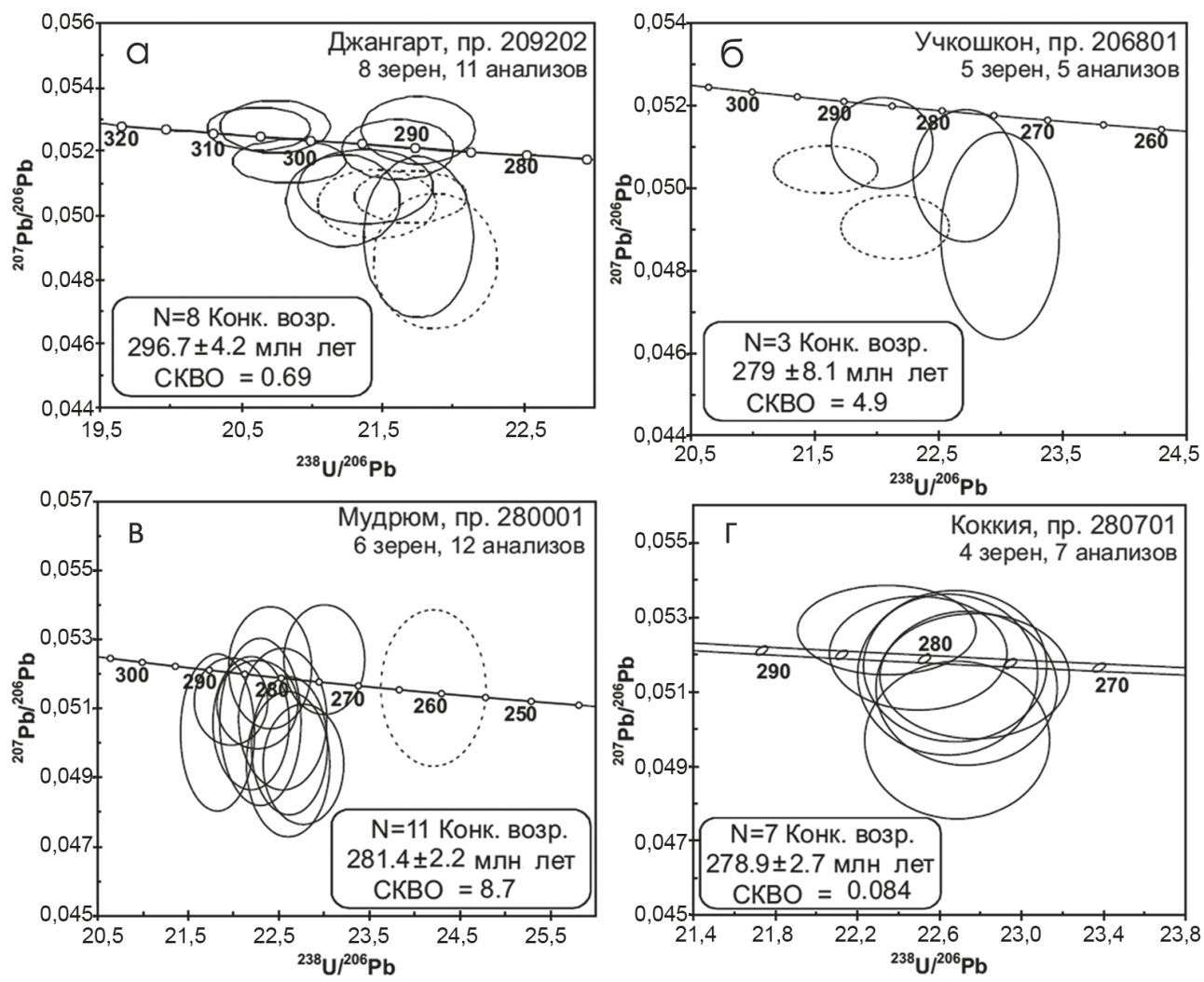

Puc. 2.10. Результаты U-Pb датирования гранитоидов Кокшаальского комплекса на диаграммах с конкордией:

а - Джангартский массив; 6 - Учкошконский; в - Мудрюмский; г - Коккиинский.

Пунктиром показаны эллипсы, соответствующие анализам, исключенным из расчета возрастов.

Номера проб соответствуют Приложению В.2

${ }^{206} \mathrm{~Pb} /{ }^{238} \mathrm{U}$ возраст $283 \pm 9$ млн лет $(\mathrm{CKBO}=0,46)$. Если два дискордантных анализа исключить из расчетов, то на основании трех оставшихся можно вычислить конкордантный возраст $279 \pm 8$ млн лет $($ СКВО $=4,9)$.

Все 12 анализов из Мудрюмского массива являются конкордантными и позволяют вычислить средневзвешенный ${ }^{206} \mathrm{~Pb} /{ }^{238} \mathrm{U}$ возраст $280 \pm 6$ млн лет $(\mathrm{CKBO}=0,49)$. Однако, если исключить из расчетов один молодой возраст, 11 оставшихся анализов позволяют рассчитать конкордантный возраст $281 \pm 2$ млн лет $($ СКВО = 8,7). Семь анализов цирконов из Коккиинской интрузии позволяют рассчитать средневзвешенный ${ }^{206} \mathrm{~Pb} /{ }^{238} \mathrm{U}$ возраст $281 \pm 7$ млн лет $(\mathrm{CКВО}=0,034)$ и конкордантный возраст $281 \pm 3$ млн лет $(\mathrm{CКВО} \mathrm{=0,084).}$

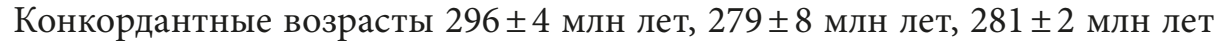
и $281 \pm 3$ млн лет интерпретируются нами как возраст кристаллизации цирконов из Джангартского, Учкошконского, Мудрюмского и Коккиинского мас- 
сивов соответственно. Возраст $296 \pm 4$ млн лет, полученный для Джангартского массива, совпадает в пределах ошибки с возрастом близкого по составу Акшийрякского массива $(292 \pm 3$ млн лет), который был также определен нами методом SHRIMP по цирконам [Konopelko et al., 2006; Seltmann et al., 2011]. Таким образом, формирование интрузий гранитов Кокшаальского комплекса происходило в интервале 295-280 млн лет, при этом овоидные гранитоиды Джангартского и Акшийрякского массивов, по-видимому, внедрились на 10-15 млн лет раньше, чем интрузии лейкогранитов.

\subsection{4. Петрогенезис гранитов}

Интрузии Кокшаальского комплекса являются многофазными. Некоторые из них вмещают месторождения олова, связанные с грейзенезацией наиболее поздних дифференцированных лейкогранитов. Это указывает на индивидуальные особенности процессов дифференциации, которые могли существенно отличаться друг от друга в разных массивах. Геохимические данные, представленные в настоящей работе, позволяют выявить только общий эволюционный тренд, характерный для массивов Кокшаальского комплекса. Этот общий тренд, являющийся типичным для А-гранитов, отражает последовательное формирование амфибол-биотитовых гранитов, биотитовых гранитов и топазсодержащих лейкогранитов. В этой серии пород процессы дифференциации приводят к последовательному увеличению концентраций $\mathrm{Si}, \mathrm{Rb}, \mathrm{Nb}, \mathrm{F}, \mathrm{Ga}, \mathrm{Sn}$, HREE (а также $\mathrm{Fe} /\left(\mathrm{Fe}+\mathrm{Mg}\right.$ ), $\mathrm{ASI}, \mathrm{Eu} / \mathrm{Eu}^{*}$ ) и уменьшению содержаний $\mathrm{Ti}, \mathrm{Al}, \mathrm{Fe}$, $\mathrm{Mg}, \mathrm{Mn}, \mathrm{Ca}, \mathrm{Ba}, \mathrm{Sr}, \mathrm{Zr}$ и LREE. Общей чертой кокшаальских гранитоидов является резкая обогащенность всех типов пород железом относительно магния, определяющая их принадлежность к толеитовой серии. Это объясняется эволюцией относительно сухих расплавов в восстановительной обстановке, которая препятствовала ранней кристаллизации магнетита и способствовала накоплению в расплавах железа. Вариации состава гранитов объясняются фракционированием калиевого полевого шпата в комбинации с каким-либо недосыщенным глиноземом силикатом (обычно амфиболом) в сочетании с небольшими количествами апатита, циркона и алланита [Rämö, Haapala, 1995]. Образование серий пород, наблюдаемых в Кокшаальском комплексе, в результате фракционирования калиевого полевого шпата и амфибола иллюстрируется трендами составов пород на вариационных диаграммах вес. \% $\mathrm{Al}_{2} \mathrm{O}_{3}$ vs. вес. $\% \mathrm{SiO}_{2}$, ppm Eu vs. вес. \% $\mathrm{SiO}_{2}$ и ASI vs. вес. \% $\mathrm{SiO}_{2}$, показанных на рис. $2.11 \mathrm{a}-2.11$ в. Снижение концентраций $\mathrm{Al}_{2} \mathrm{O}_{3}$ с ростом содержания кремнезема в породах обусловлено фракционированием породообразующих силикатов. При этом уменьшение концентраций Еu с ростом кремнезема указывает на то, что преобладающим процессом было фракционирование калиевого полевого шпата. Увеличение индекса глиноземистости ASI с ростом кремнезема свидетельствует о том, что фракционирование амфибола также являлось 

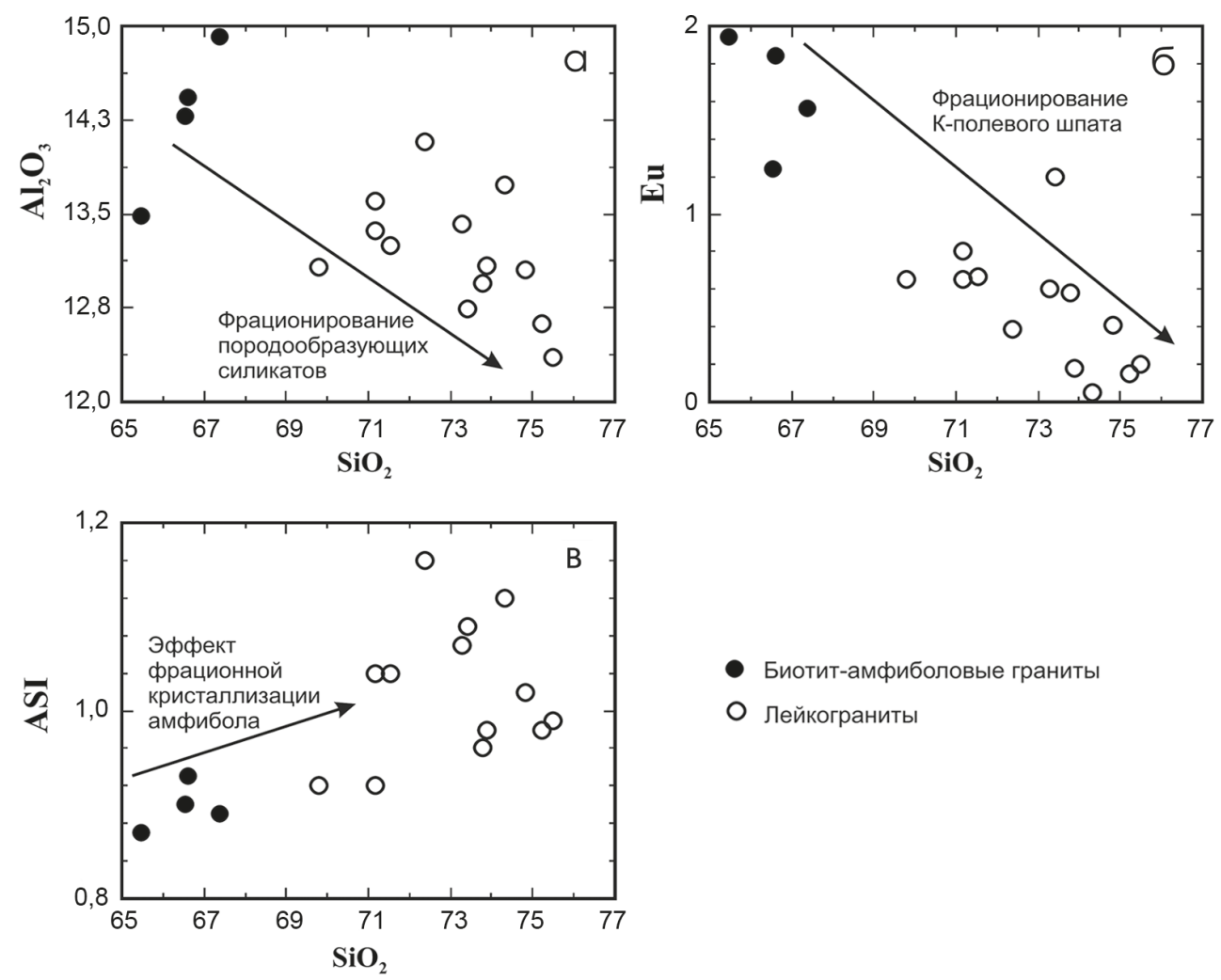

- Биотит-амфиболовые граниты

О Лейкограниты

Рис. 2.11. Химические составы гранитоидов Кокшаальского комплекса на вариационных диаграммах:

$\mathrm{a}-\mathrm{Al}_{2} \mathrm{O}_{3}$, вес. \%, vs. $\mathrm{SiO}_{2}$, вес. \%; $6-\mathrm{Eu}(\mathrm{ppm})$ vs. $\mathrm{SiO}_{2}$, вес. \%; в - $\mathrm{ASI}\left(\mathrm{Al}_{2} \mathrm{O}_{3} /\left(\mathrm{CaO}+\mathrm{Na}_{2} \mathrm{O}+\mathrm{K}_{2} \mathrm{O}\right)\right.$, мол., vs. $\mathrm{SiO}_{2}$, вес. \%

важным процессом. Это означает, что овоидные биотит-амфиболовые граниты Джангартского и Акшийракского массивов по существу представляют собой полевошпатовые кумулаты. Было предложено несколько механизмов образования А-гранитов, из которых наиболее обоснованными являются фракционирование мантийных базальтоидных расплавов, взаимодействие мантийных расплавов с коровыми породами и плавление нижних горизонтов континентальной коры [Rämö, Haapala, 1995; Bonin, 1996]. А-граниты также могут формироваться в различных геодинамических обстановках, включая анорогенную и постколлизионную. Существует разделение на две группы гранитов A-типа: A1 и A2 [Eby, 1990]. Граниты, относящиеся к группе A1, имеют мантийное происхождение и формируются во внутриплитных (анорогенных) обстановках. Граниты, относящиеся к группе А2, образуются в результате плавления континентальной коры в различных геодинамических обстановках. На дискриминационных диаграммах Rb/Nb-Y/Nb и Y-Nb-Ce [Eby, 1990] точки 


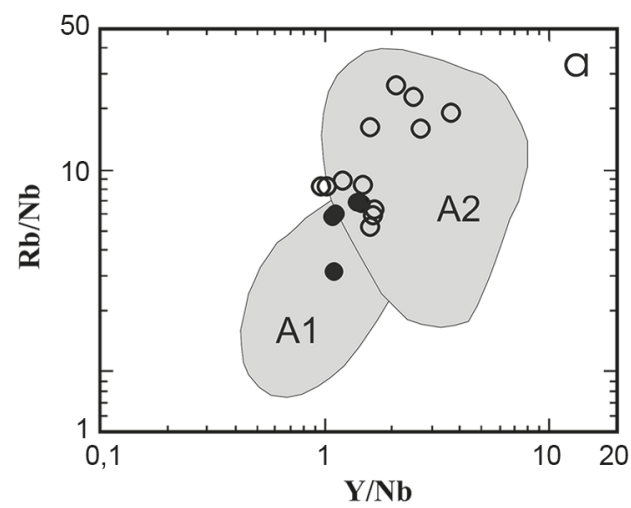

- Биотит-амфиболовые граниты

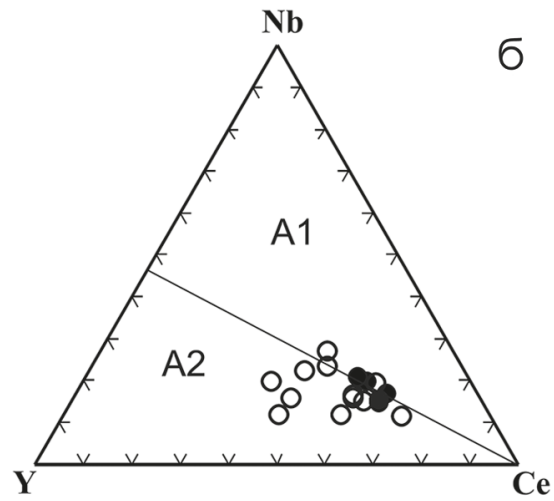

О Лейкограниты

Pис. 2.12. Химические составы гранитоидов Кокшаальского комплекса на дискриминационных диаграммах:

$\mathrm{a}-\mathrm{Rb} / \mathrm{Nb}$ vs. Y/Nb; $6-\mathrm{Y}-\mathrm{Nb}-\mathrm{Ce}$ [Eby, 1990]

составов гранитов Кокшаальского комплекса проецируются в поле гранитов A2 (рис. 2.12), что подтверждает их образование в постколлизионной обстановке из корового источника. Изотопный состав $\mathrm{Nd}$ в гранитах Кокшаала также указывает на их происхождение в результате плавления средне-позднепротерозойской или более древней континентальной коры, возможно в результате взаимодействия с некоторым количеством ювенильного мантийного вещества (см. рис. 2.9). Изотопный состав свинца, определенный [Chiaradia et al., 2006] в валовых пробах пород и в полевых шпатах гранитов Кокшаала, также указывает на докембрийский коровый источник.

В интрузиях А-гранитов Кокшаала установлены признаки одновременного внедрения с мафическими породами и щелочными сиенитами. Ассоциация с мафическими породами толеитовой серии в составе габбро-анортозит-рапакиви гранитной формации является типичной для докембрийских A-гранитов (см.: [Rämö, Haаpala, 1995; Frost C.D., Frost B.R., 1997]). Однако ассоциация со щелочными сиенитами более характерна для фанерозойских A-гранитов [Наapala et al., 2005]. На территории Кыргызстана мафические породы, ассоциирующие с интрузиями А-гранитов, представлены сравнительно небольшими телами. Однако в северной части Тарима на территории Китая описаны мощные толщи раннепермских бимодальных вулканитов с возрастами около 280 млн лет [Carrol et al., 2001; Jiang et al., 2004]. Толеитовые и щелочные базальты в составе этих вулканических покровов могут представлять собой материал астеносферной мантии, подъем которой на постколлизионной стадии в результате андерплэйтинга обеспечил привнос тепла и плавление докембрийской коры Тарима с образованием А-гранитов. Значения $\varepsilon \mathrm{Ndt}$ от -3,7 до 0 в базальтах Тарима [Jiang et al., 2004] лишь незначительно выше зна- 
чений $\varepsilon \mathrm{Ndt}$ в A-гранитах Кокшаала (см. рис. 2.9), что указывает на смешение мантийного и корового компонентов в обеих сериях пород.

\section{§ 2.3. Малые интрузии дифференцированных лейкогранитов восточной части Кокшаала и известково-щелочные массивы в зоне Атбаши-Иныльчекского разлома}

Дифференцированные оловоносные лейкограниты, слагающие несколько малых интрузий в восточной части Кокшаала, описаны в составе Иныльчекского подкомплекса Кокшаальского регионального комплекса [Додонова, 1974; Стратифицированные..., 1982; Трифонов, Соломович, 1993; Solomovich, Trifonov, 2002]. Некоторые интрузии Иныльчекских лейкогранитов расположены в непосредственной близости от Атбаши-Иныльчекского разлома, в зоне которого размещаются массивы известково-щелочных гранитоидов (І-типа) Уланского и Теректинского комплексов (см. рис. 2.2, 2.3). Массивы известково-щелочных гранитоидов расположены в зоне Атбаши-Иныльчекского разлома к северу от главного структурного шва Южно-Тянь-Шаньской сутуры, то есть на территории Срединного Тянь-Шаня. Они вытянуты вдоль зоны разлома и ограничены с юга структурным швом, параллельно которому в гранитоидах развита мощная зона бластокатаклазитов и милонитов. Фотография Теректинского известково-щелочного массива, обнажающегося в Сарыджазском хребте к северу от Атбаши-Иныльчекского разлома и Ташкоринского штока оловоносных лейкогранитов, примыкающего к линии разлома с юга, приведена на рис. 2.13. Так как изотопное датирование показало, что известково-щелочные гранитоиды и оловоносные лейкограниты формировались практически одновременно, дадим сравнительную характеристику пород Теректинского и Иныльчекского комплексов и рассмотрим возможный сценарий их образования.

Иньльчекский подкомплекс включает небольшие по размерам интрузивы: Ташкоринский, Майдаадырский, Суходольский, Иныльчекский, Атджайляуский, Комсомольский, Майбашский, Джеткайский, расположенные в восточной части Кокшаальского сегмента Южного Тянь-Шаня (см. рис. 2.2, 2.3). Значительную по объему часть Иныльчекского подкомплекса составляют дифференцированные оловоносные редкометальные литий-фтористые граниты: субщелочные двуполевошпатовые и микроклин-альбитовые лейкограниты, амазонитовые граниты, онгониты и эльваны [Трифонов, Соломович, 1993; Solomovich, Trifonov, 2002]. Некоторые массивы сложены крупнозернистыми биотитовыми гранитами, сходными по облику с гранитами Учкошконского подкомплекса. Следует отметить, что наименее дифференцированные 


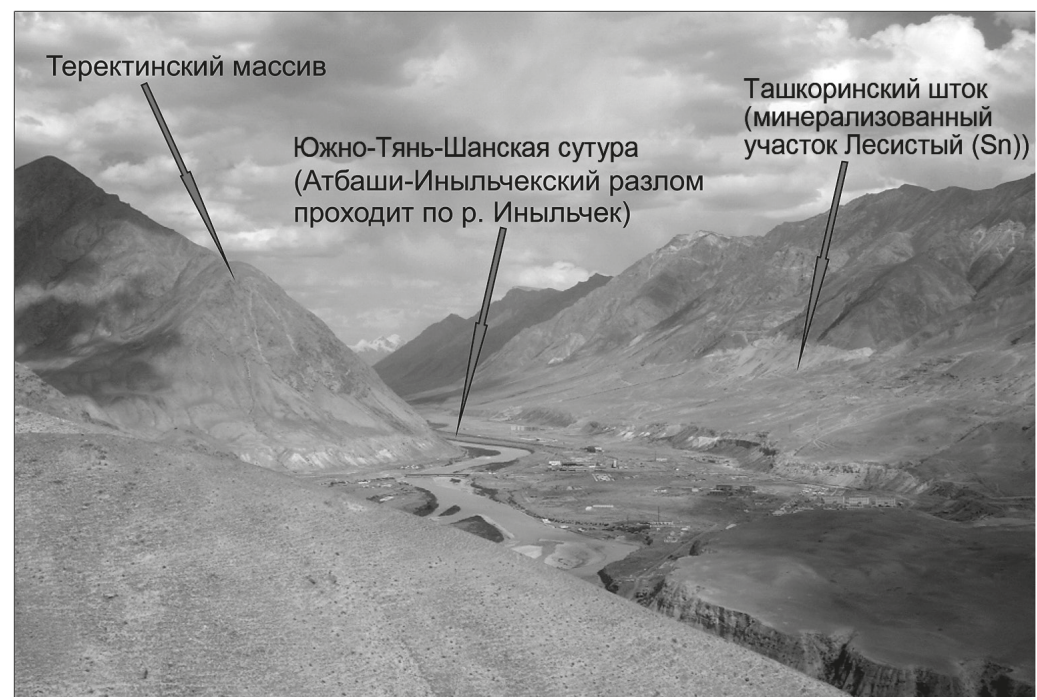

Puc. 2.13. Находящиеся по разные стороны Атбаши-Иныльчекского разлома Теректинский известково-щелочной массив и Ташкоринский шток оловоносных лейкогранитов

граниты, описанные в составе Майдаадырского и Майбашского массивов, представлены амфиболсодержащими разновидностями с относительно пониженным содержанием кремнезема.

По данным Э.Б. Байбулатова с соавторами, главные типы пород, слагающие интрузии Иныльчекского комплекса, включают:

1. Небольшие тела наиболее мафических амфибол- и/или пироксенсодержащих монцонитов и гранитов, описанные в Комсомольском и Ташкоринском массивах [Гранитоиды..., 1973]. В Ташкоринском массиве такие включения небольшого размера (около $10 \mathrm{~cm}$ ) с признаками одновременного внедрения и геохимическими особенностями высокоглиноземистых толеитовых базальтов (Приложение Б.2) местами особенно распространены.

2. Крупнозернистые порфировидные биотитовые граниты и лейкограниты, являющиеся главной разновидностью в Майдаадырском и Ташкоринском массивах. Фотографии типичных биотитовых лейкогранитов из штока Ташкоро приведены на рис. 2.14а и 2.146. На этом рисунке также приведены фотографии грейзенизированных обогащенных турмалином лейкогранитов (рис. 2.14в, 2.14г), которые показывают, как развивается процесс грейзенизации, приводящий к образованию богатых касситеритовых руд, изученных в штольне минерализованного участка Лесистый (рис. 2.14д, 2.14е). Среднезернистые биотитовые лейкограниты обычно секут крупнозернистые 

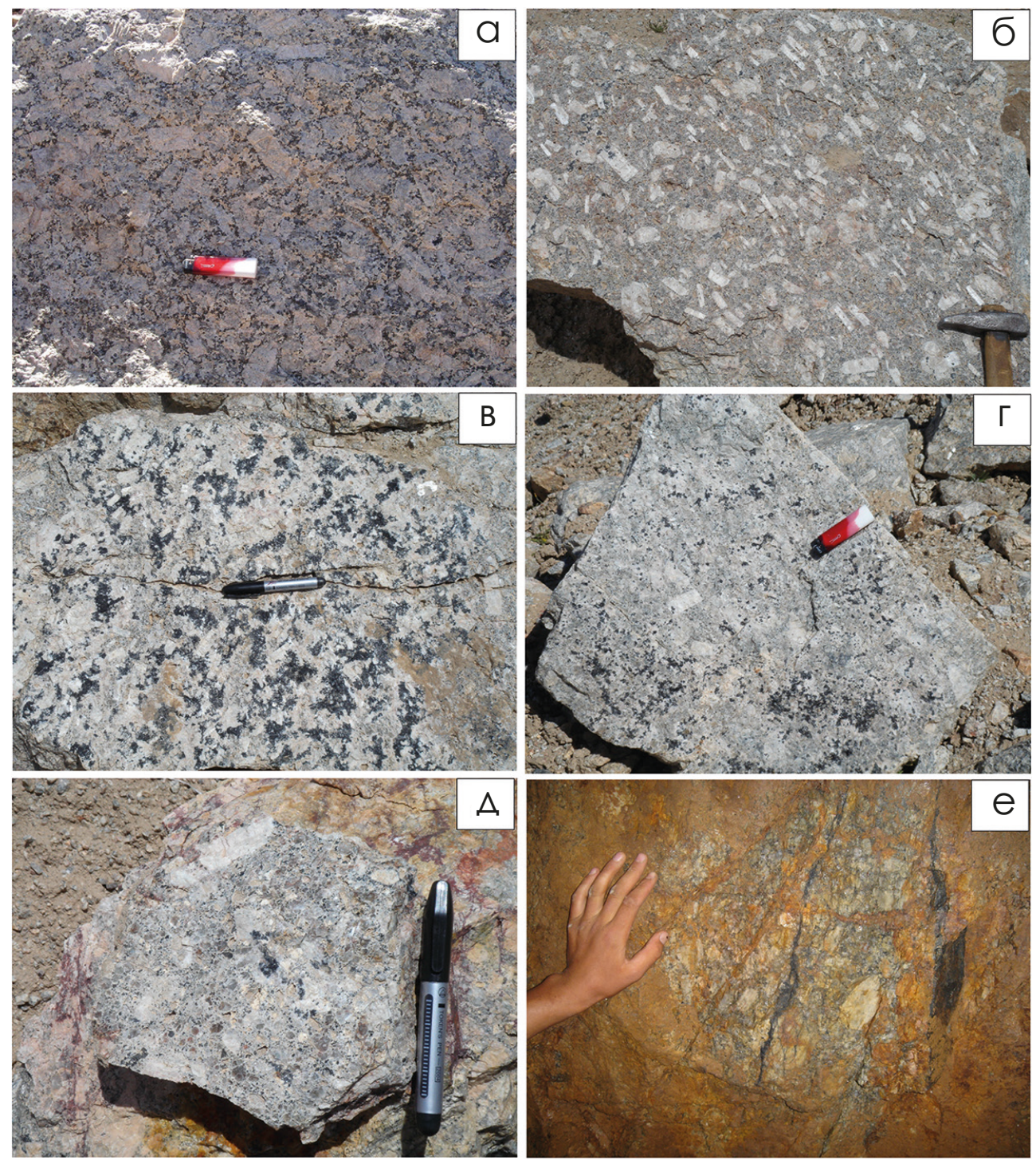

Pис. 2.14. Фотографии главных типов пород Ташкоринского штока:

а - порфировидные лейкограниты с массивной текстурой; б - порфировидные лейкограниты с трахитоидной текстурой; в, г - грейзенизированные обогащенные турмалином лейкограниты; д - интенсивно грейзенизированный лекогранит; е - интенсивно грейзенизированный лейкогранит с рудными прожилками в штольне минерализованного участка Лесистый

граниты в Ташкоринском и Майдаадырском массивах и преобладают в интрузиях Иныльчек и Атджайляу.

3. Наконец, циннвальдитсодержащие лейкограниты, слагающие большую часть Суходольского и Комсомольского штоков. Эти породы 
часто характеризуются зеленоватой окраской благодаря наличию амазонита и содержат миароловые пустоты, наиболее крупные из которых часто выполнены циннвальдитом, полихромным турмалином и другими редкометальными фазами [Solomovich, Trifonov, 2002]. Наряду с касситерит-сульфидным оруденением (месторождение Сарыджаз, связанное с Ташкоринским штоком) с лейкогранитами Иныльчекского подкомплекса связано поле редкометальных пегматитов в осевой части одноименного хребта [Руб, Павлов, 1982].

Рассмотрим гранитоиды зоны Атбаши-Иныльчекского разлома.

Уланский (Сонкульский) комплекс представлен Уланским массивом, который ранее традиционно делился на Западно- и Восточно-Уланский массивы, относимые к Сонкульскому и Теректинскому комплексам соответственно [Додонова, 1974; Стратифицированные..., 1982]. Оба массива расположены в зоне Атбаши-Иныльчекского разлома и вытянуты вдоль него на 55 км при максимальной ширине 6 км. На юге они срезаются Атбаши-Иныльчекским структурным швом, параллельно которому в гранитоидах развита мощная зона бластокатаклазитов и милонитов. Северный контакт перекрыт аллювиальными отложениями р. Нарын. Западно-Уланский массив, отождествляемый с первой фазой комплекса, сложен габброидами с отчетливыми признаками расслоенности. Следует отметить широкое распространение здесь оливиновых габброноритов и находки габброидов субщелочного ряда. Восточно-Уланский массив сложен амфибол-биотитовыми гранодиоритами, представляющими вторую фазу комплекса. Контакт между породами первой и второй фаз скрыт под аллювиальными отложениями р. Улан. В зоне контакта гранодиориты второй фазы вмещают небольшие тела пегматитов, содержащих турмалин и гранат. Гранодиориты представляют собой средне- и крупнозернистые породы с резко идиоморфной роговой обманкой, богатые акцессорными минералами. Их минеральный состав: плагиоклаз (40-60\%), кварц (15-25\%), калишпат (0-20\%), биотит (5-15\%), амфибол (0-15\%). Акцессории: апатит, магнетит, сфен, циркон, ортит. На диаграмме Штрекайзена породы массива попадают в поля диорита, монцодиорита и их кварцевых разностей, а также плагиогранита, гранодиорита и адамеллита, что соответствует классическому тренду известково-щелочной серии. С породами Уланского массива связаны проявления полиметаллов и золота. Следует отметить, что амфибол-биотитовые гранодиориты встречены также в составе Теректинского массива и Бешмойнокских тел. Гранодиориты резко отличаются от преобладающих в этих массивах лейкократовых биотитовых адамеллитов и рассматриваются нами в рамках Уланского комплекса.

К Теректинскому комплексу относятся биотитовые адамеллиты, слагающие основную часть Теректинского массива, расположенного на южном склоне Сарыджазского хребта по правобережью р. Иныльчек и вытянутого на 87 км при ширине от 6,5 до 0,5 км. Контакты массивов повсеместно тектонические. 


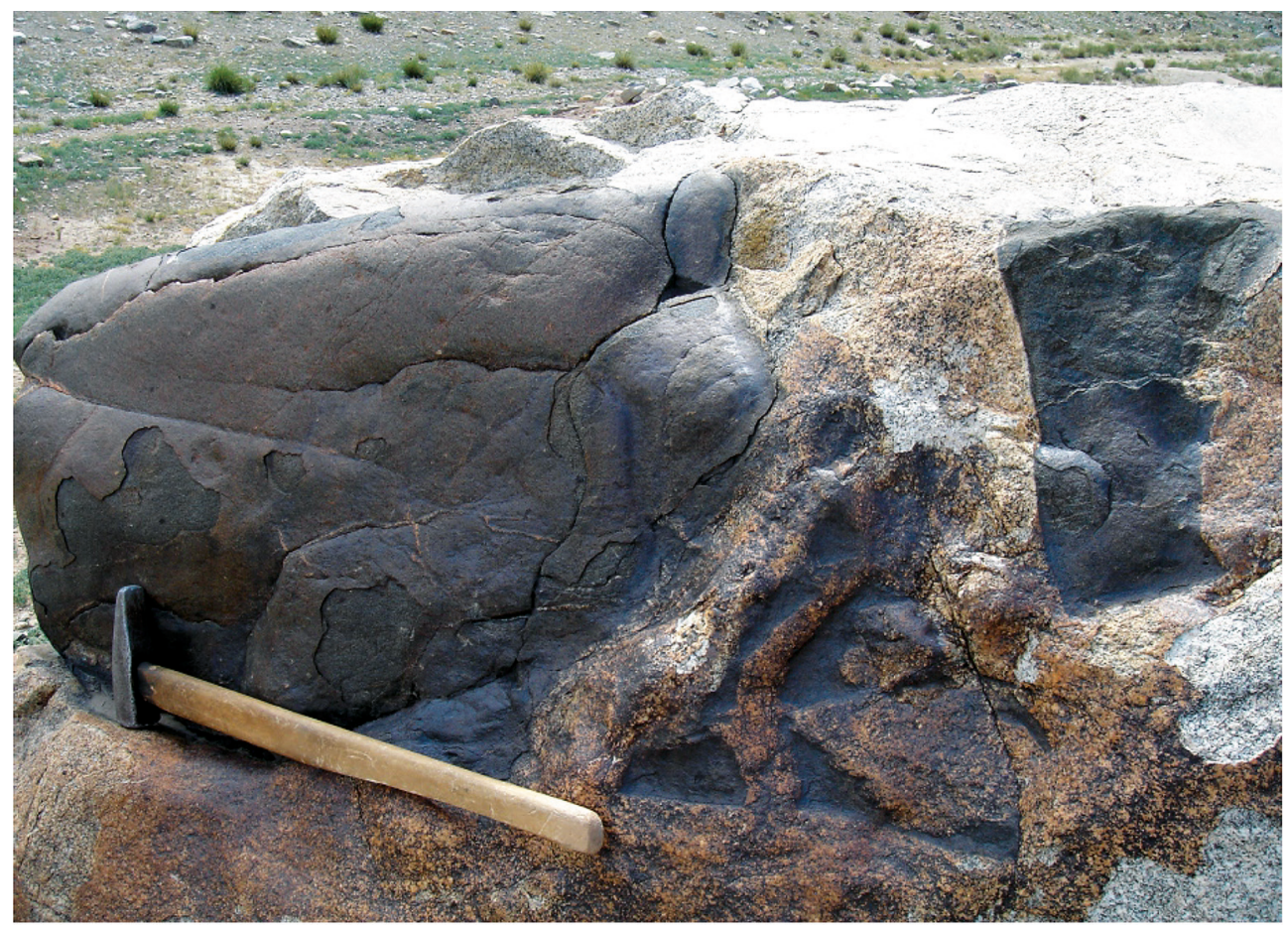

Pис. 2.15. Включение диоритоидного состава в гранодиорите Теректинского массива, опробованное для датирования по цирконам

В строении Теректинского массива также принимают участие амфибол-биотитовые гранодиориты, гранатсодержащие мигматиты и мусковитовые граниты, многочисленные включения диоритов и ксенолиты кристаллосланцев, гнейсов, амфиболитов [Стратифицированные..., 1982]. Минеральный состав гнейсовидных и порфировидных биотитовых гранитов: олигоклаз (30-50\%), микроклин (20-40\%), кварц (20-30\%), биотит (5-10\%). Акцессории: магнетит, циркон, сфен, апатит, ортит. Породы массива относились различными авторами к трем или четырем интрузивным фазам. Адамеллиты Теректинского комплекса не имеют отчетливой металлогенической специализации. Бешмойнокские тела сложены милонитизированными лейкократовыми адамеллитами, сложенными кислым плагиоклазом (30\%), микроклином (25\%), кварцем (40\%), а также небольшими количествами биотита, мусковита и магнетита (менее $1 \%$ ). В двухтомном труде «Стратифицированные и интрузивные образования Киргизии» Теректинский массив рассматривался в качестве моногенной интрузии [Стратифицированные..., 1982]. Однако Оттукская геологическая партия выделила в пределах массива два комплекса: Каиндыбулакский предположительно силурийского возраста и Теректинский карбоновый [Геологическая съемка..., 1985]. К Каиндыбулакскому комплексу были отнесены интенсивно 
катаклазированные и милонитизированные граниты с многочисленными ксенолитами метаморфических пород и включениями диоритов, кварцевых диоритов и монцодиоритов. Менее деформированные однородные граниты были отнесены к Теректинскому комплексу. Для того чтобы изучить геохимические особенности и датировать обе эти серии пород, нами были отобраны пробы из крупного включения амфиболовых диоритов и из типичного порфировидного амфибол-биотитового гранодиорита (рис. 2.15).

\subsection{1. Результаты U-Pb датирования цирконов}

Для датирования $\mathrm{U}-\mathrm{Pb}$ методом по цирконам были выбраны пять разновидностей пород. Две пробы гранитоидов Теректинского комплекса включают типичный амфибол-биотитовый слабо гнейсовидный гранит (пр. 416000) и амфиболовый диорит из крупного (диаметром около 50 м) включения в гранитах (пр. 416705). Три пробы представляют Иныльчекский комплекс и включают крупнозернистый порфировидный амфибол-биотитовый гранит из штока Ташкоро (пр. 416506), равномернозернистый гранит минерализованного участка Лесистый из Иныльчекского штока (пр. 416801) и лейкогранит Майдаадырского массива (пр. 416803).

Возраст пяти гранитоидов Иныльчекского комплекса был определен с помощью U-Pb датирования цирконов in situ. Анализ U-Th-Pb изотопного состава цирконов был выполнен с помощью ионного микрозонда SHRIMP-II в лаборатории ВСЕГЕИ в Санкт-Петербурге. Детали аналитической процедуры были опубликованы нами ранее [Konopelko et al., 2009]. Аналитические результаты и диаграммы с конкордией [Tera, Wasserburg, 1974] представлены в Приложении В.3 и на рис. 2.16. Расчет возрастов производился с помощью программы Isoplot/Ex v. 2.05 [Ludwig, 1999].

Цирконы, выделенные из пяти проб, представлены достаточно однородными, хорошо ограненными призматическими зернами размером 200-400 микрон с типичной магматической зональностью на катодолюминесцентных изображениях.

Девять анализов in situ были выполнены в девяти зернах циркона из амфиболсодержащего гранита штока Ташкоро (пр. 416506). Изотопные составы всех проанализированных зерен являются конкордантыми и позволяют вычислить конкордантный возраст $299 \pm 4$ млн лет (СКВО = 0,068).

Шесть анализов, выполненные в шести зернах циркона, выделенных из гранита минерализованного участка Лесистый в штоке Иныльчек (пр. 416801), также являются конкордантными и позволяют вычислить конкордантный возраст $295 \pm 4$ млн лет $($ СКВО = 1,05).

Восемь анализов, выполненные в восьми зернах циркона, выделенных из гранита Майдаадырского массива, также проецируются на линию конкордии или вблизи нее. Если один слабо дискордантный анализ исключить 

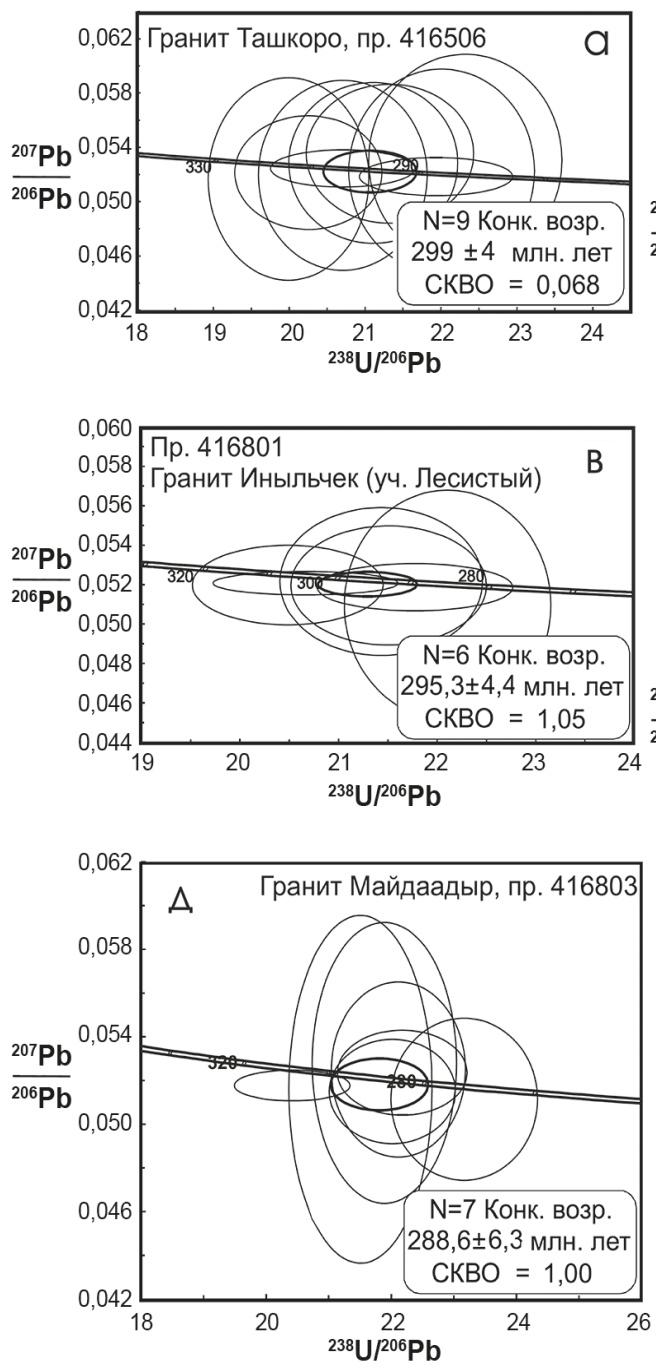
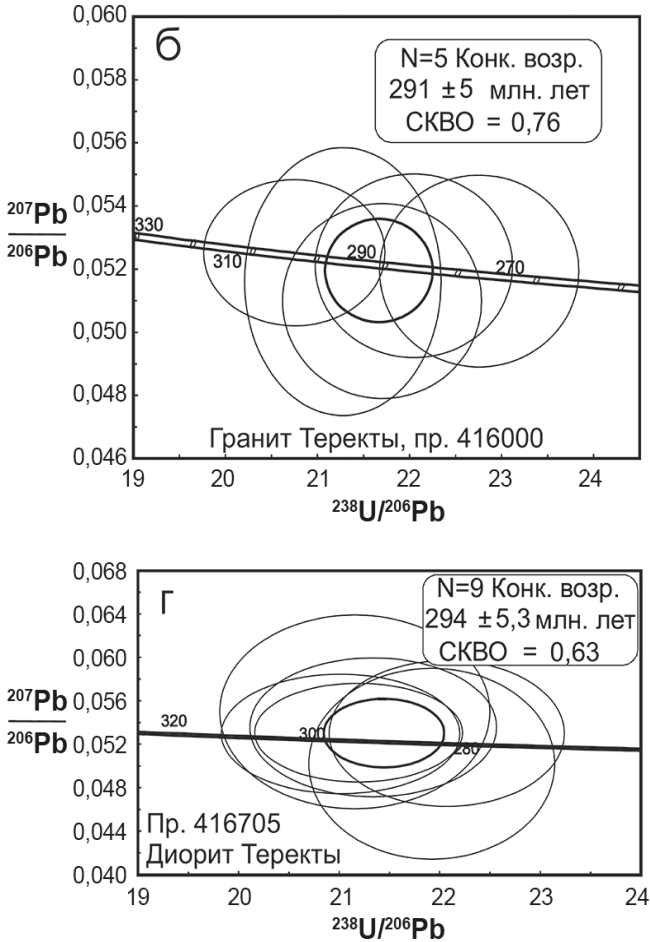

Puc. 2.16. Результаты U-Pb датирования гранитоидов Иныльчекского и Теректинского комплексов на диаграммах с конкордией (номера проб соответствуют Приложению В.3): а - гранит Ташкоринского штока; 6 - гранит Теректинского массива; в - гранит Иныльчекского массива из минерализованного участка Лесистый; г - диорит Теректинского массива; д - гранит Майдаадырского массива

из расчетов, остальные семь анализов позволяют рассчитать конкордантный возраст $289 \pm 6$ млн лет $($ СКВО $=1,00)$.

Пять анализов, выполненные в шести зернах циркона, выделенных из гранита Теректинского массива (пр. 416000), являются конкордантными и позволяют вычислить конкордантный возраст $291 \pm 5$ млн лет $(\mathrm{CКBО} \mathrm{=0,094).}$

Шесть анализов, выполненные в шести зернах циркона, выделенных из гранита Теректинского массива (пр. 416705), также являются конкордантными и позволяют вычислить конкордантный возраст $294 \pm 5$ млн лет $(\mathrm{CKBO}=0,63)$. 
Таким образом, для всех пяти проб гранитоидов получены конкордантные возрасты, которые интерпретируются как возраст кристаллизации соответствующих интрузий. Обращает на себя внимание то, что для всех пяти пород получены близкие возрасты в интервале 289-299 млн лет, которые совпадают в пределах ошибки измерения.

\subsection{2. Геохимия}

Химические анализы главных типов магматических пород Теректинского и Иныльчекского комплексов приведены в Приложении Б.2. Концентрации петрогенных и редких элементов определены в лабораторатории ВСЕГЕИ в Санкт-Петербурге; аналитические методы описаны нами ранее [Konopelko et al., 2009]. Для того чтобы полнее охарактеризовать геохимические особенности пород, мы также вынесли на диаграммы анализы химического состава пород из отчетов о геологической съемке (см. также: [Додонова, 1974; Геологическая съемка..., 1985]) и аналитические результаты [Solomovich, Trifonov, 2002].

На классификационной диаграмме TAS [Middlemost, 1994] составы гранитоидов обоих комплексов попадают в поля диорита, гранодиорита и гранита, образуя тренд в поле субщелочной серии (рис. 2.17a). Исключением являются граниты штока Ташкоро, которые проецируются в поле щелочной серии. Гранитоиды Теректинского комплекса резко отличаются от гранитоидов Иныльчекского комплекса по значениям отношений $\mathrm{FeO} / \mathrm{MgO}$, что хорошо видно на диаграмме $\mathrm{FeO}^{\text {tot }} /\left(\mathrm{FeO}^{\text {tot }}+\mathrm{MgO}\right)$ vs. вес. \% $\mathrm{SiO}_{2}$ (рис. 2.176 ), на которую нанесено поле средних составов А-гранитов мира [Frost et al., 2001]. Большинство пород Иныльчекского комплекса характеризуются очень высокими значениями $\mathrm{FeO}^{\text {tot }} /\left(\mathrm{FeO}^{\text {tot }}+\mathrm{MgO}\right)$ от 0,8 до 1,0 и проецируются в поле гранитоидов толеитовой серии (железистых) и в поле гранитов А-типа, тогда как большая часть составов пород Теректинского комплекса попадает в поле гранитоидов известково-щелочной серии (магнезиальных). На диаграмме ( $\mathrm{Na}+\mathrm{K}) / \mathrm{Al}$ (ат.) vs. $10000^{\star} \mathrm{Ga} / \mathrm{Al}$ (рис. 2.17в) гранитоиды обоих комплексов попадают в поле субщелочной серии. Однако они существенно отличаются друг от друга по значению отношений $\mathrm{Ga} / \mathrm{Al}$ : гранитоиды Терктинского комплекса проецируются на этой дискриминационной диаграмме в поле M-, I- и S-гранитов, а точки составов Иныльчекских пород попадают в поле А-гранитов. На диаграмме $\mathrm{Al}_{2} \mathrm{O}_{3}$ / $\left(\mathrm{CaO}+\mathrm{Na}_{2} \mathrm{O}+\mathrm{K}_{2} \mathrm{O}\right)$, мол., vs. $\mathrm{SiO}_{2}$ (рис. 2.17г) породы обоих комплексов попадают в поле умеренно глиноземистых составов или слабо пересыщены глиноземом (ASI до 1,15), однако обращает на себя внимание тот факт, что большая часть пород Иныльчекского комплекса пересыщена глиноземом. Диаграмма $\left(\mathrm{Na}_{2} \mathrm{O}+\mathrm{K}_{2} \mathrm{O}\right) / \mathrm{CaO}$ vs. $10000^{*} \mathrm{Ga} / \mathrm{Al}$ еще раз показывает, что гранитоиды Теректинского комплекса характеризуются пониженными значениями отношений $\mathrm{Ga} / \mathrm{Al}$, по сравнению с гранитоидами Иныльчекского комплекса (рис. 2.18a). Кроме того, гранитоиды Иныльчекского комплекса имеют отчетливую специ- 

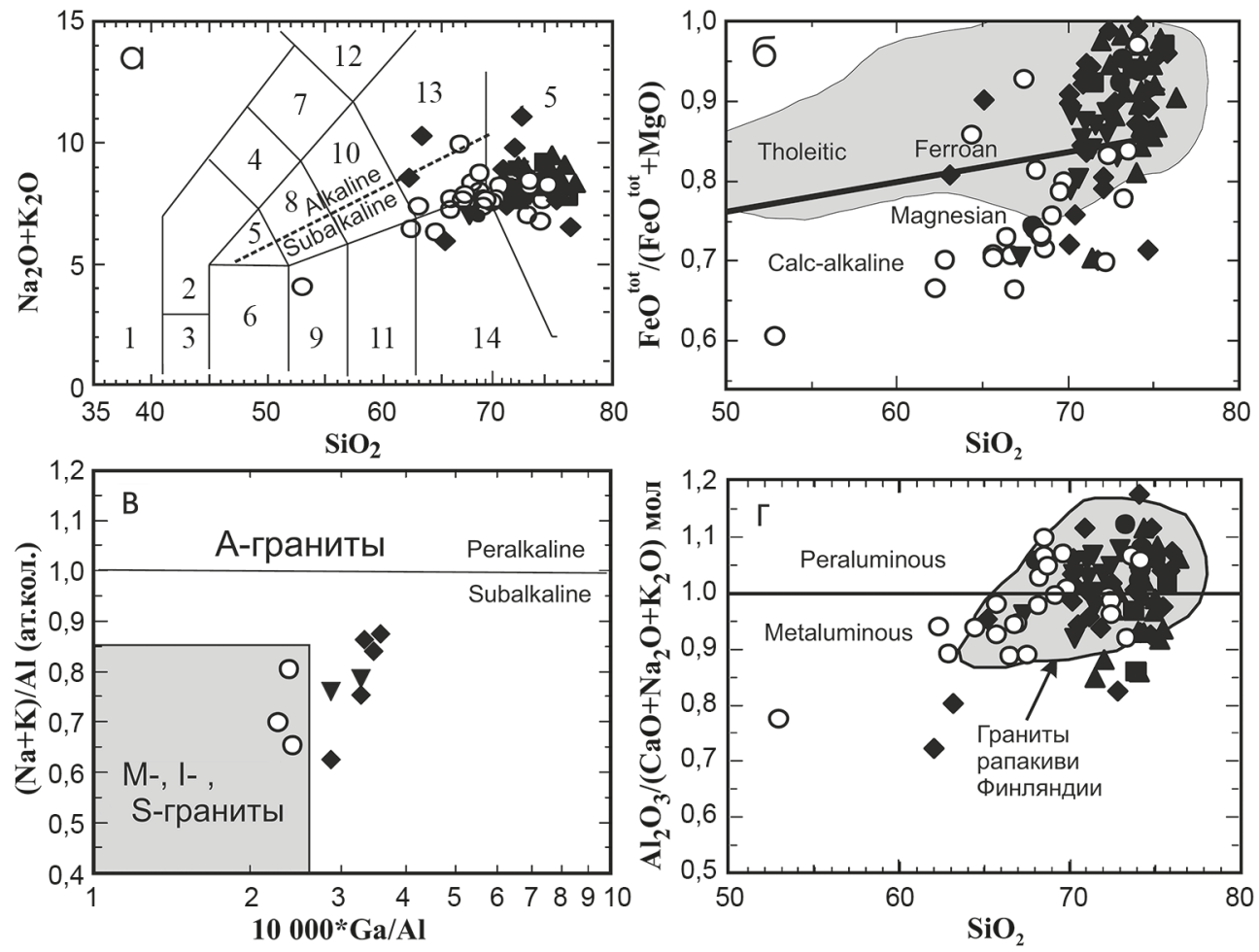

○ Теректинский массив

Иныльчекский комплекс: $\diamond$ Ташкоро, $\Delta$ Иныльчек,

- Суходольский, $\nabla$ Майдаадыр, — Атджайляу, О Комсомольский

Рис. 2.17. Химические составы гранитоидов Иныльчекского и Теректинского комплексов на классификационных и дискриминационных диаграммах:

a - диаграмма TAS $\left(\mathrm{Na}_{2} \mathrm{O}+\mathrm{K}_{2} \mathrm{O}\right)$ vs. $\mathrm{SiO}_{2}$, вес. \%, где названия полей даны по [Middlemost, 1994]: 1 - фойдолит, 2 - фельдшпатоидное габбро, 3 - габброперидотит, 4 - фельдшпатоидный монцодиорит, 5 - монцогаббро, 6 - габбро, 7 - фельдшпатоидный монцосиенит, 8 -

монцодиорит, 9 - габбродиорит, 10 - монцонит, 11 - диорит, 12 - фельдшпатоидный сиенит, 13 - сиенит и кварцевый монцонит, 14 - гранодиорит, 15 - гранит; 6 - диаграмма

$\mathrm{FeO} /\left(\mathrm{FeO}^{\text {tot }}+\mathrm{MgO}\right)$ vs. $\mathrm{SiO}_{2}$, вес. \%, с серым полем составов А-гранитов мира, по [Frost et al., 2001]; в - дискриминационная диаграмма ( $\mathrm{Na}+\mathrm{K}) / \mathrm{Al}$, ат. кол., vs. $10000 * \mathrm{Ga} / \mathrm{Al}$, по [Whalen et al., 1987];

г - индекс глиноземистости ASI (= $\mathrm{Al}_{2} \mathrm{O}_{3} /\left(\mathrm{Na}_{2} \mathrm{O}+\mathrm{K}_{2} \mathrm{O}+\mathrm{CaO}\right)$, мол., vs. $\mathrm{SiO}_{2}$ с полем составов гранитов рапакиви Финляндии, по [Rämö, Haapala, 1995]

ализацию на олово (от 10 до 100 ppm), в то время как гранитоиды Теректинского комплекса характеризуются кларковыми значениями содержаний олова менее 5 ppm (рис. 2.186).

Спектры распределения REE в гранитоидах Теректинского комплекса умеренно фракционированы и характеризуются небольшими отрицательными Eu аномалиями (рис. 2.19a). Спектры распределения концентраций редких элементов в гранитоидах Теректинского комплекса, представленные на мультикатионных диаграммах (см. рис. 2.19a), демонстрируют умеренное 

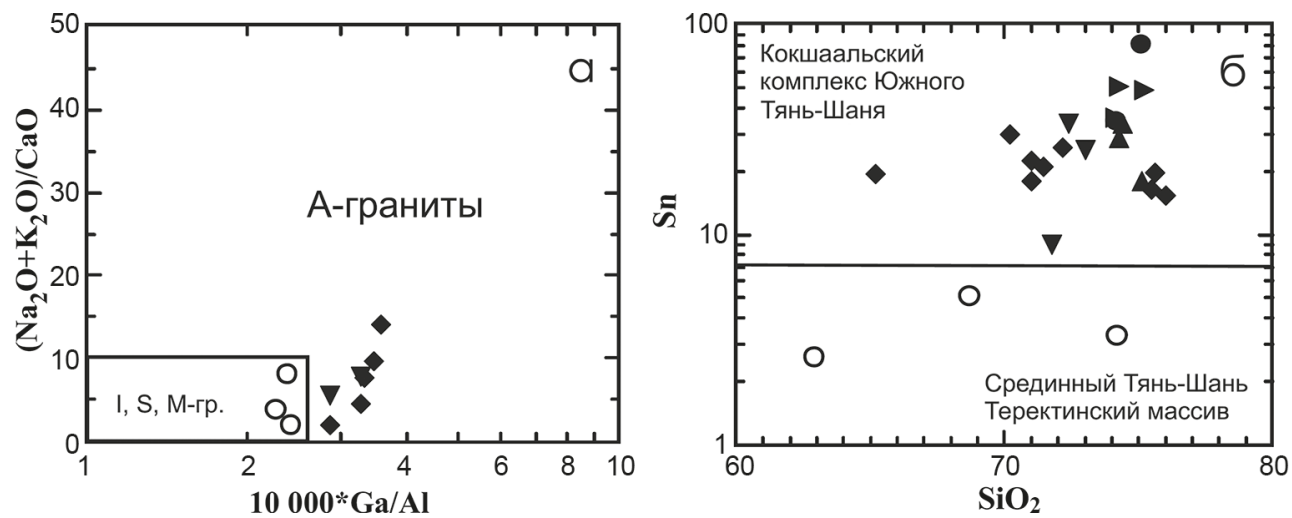

Puс. 2.18. Химические составы гранитоидов Иныльчекского (Кокшаальского) и Теректинского комплексов: а - на дискриминационной диаграмме [Whalen et al., 1987] $\left(\mathrm{Na}_{2} \mathrm{O} \pm \mathrm{K}_{2} \mathrm{O}\right) / \mathrm{CaO}$ vs.

$10000 * \mathrm{Ga} / \mathrm{Al} ; 6$ - на вариационной диаграмме Sn vs. $\mathrm{SiO}_{2}$. Условные обозначения см. на рис. 2.17
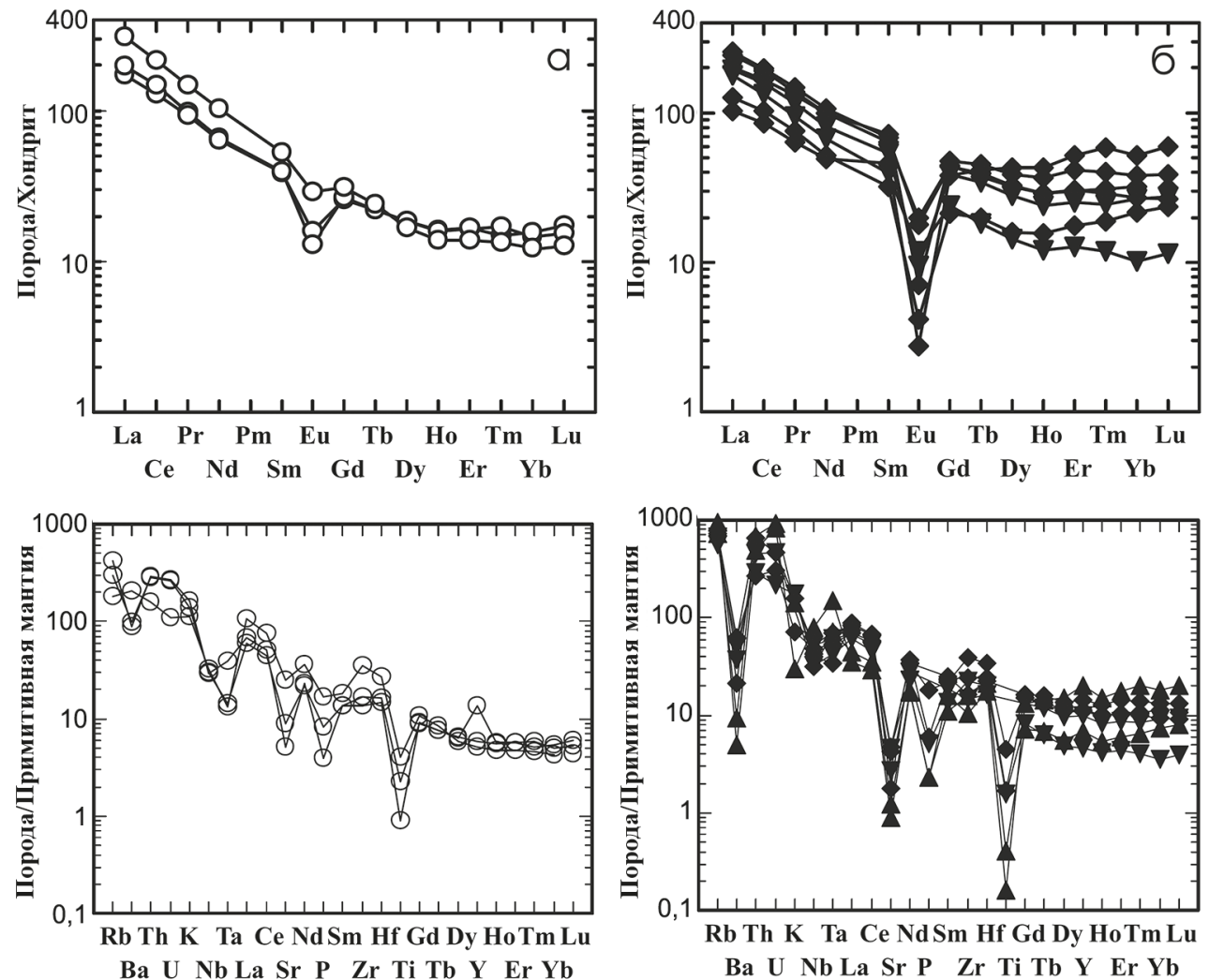

Rb Th K Ta Ce NdSm Hf Gd Dy HoTm Lu Ba U Nb La Sr P Zr Ti Tb Y Er Yb

PUc. 2.19. Нормированные к хондриту спектры распределения концентраций REE и нормированные к примитивной мантии спектры распределения концентраций редких элементов в гранитоидах Теректинского массива (а) и малых интрузий Иныльчекского комплекса (б). Для нормирования использовались значения концентраций из [Sun, McDonough, 1989]. Условные обозначения см. на рис. 2.17 
обогащение литофильными элементами и отчетливые отрицательные аномалии высокозарядных катионов $\mathrm{Nb}$, Та и Тi, что является типичным для островодужных гранитоидов.

Спектры распределения REE в гранитах Иныльчекского комплекса слабо фракционированы и характеризуются резкими отрицательными Еu аномалиями (рис. 2.196). Характерными чертами являются уменьшение содержаний легких REE, относительное увеличение содержаний тяжелых REE и резко выраженные отрицательные аномалии Еu в наиболее дифференцированных разновидностях лейкогранитов. Спектры распределения концентраций редких элементов в гранитоидах Иныльчекского комплекса, представленные на мультикатионных диаграммах (см. рис. 2.196), демонстрируют резкое обогащение литофильными элементами, отсутствие выраженных отрицательных аномалий $\mathrm{Nb}, \mathrm{Ta}$ и отчетливые отрицательные аномалии $\mathrm{Ba}, \mathrm{Sr}, \mathrm{P}$ и Ti.

Различный характер спектров распределения REE и редких элементов в гранитоидах Теректинского и Иныльчекского комплексов может определяться их происхождением из различных коровых источников. В частности, относительное обеднение Теректинских гранитоидов тяжелыми REE указывает на присутствие граната в субстрате, из которого были выплавлены эти породы.

\subsection{3. Петрогенезис гранитов}

Гранитоиды Теректинского комплекса характеризуются содержаниями $\mathrm{SiO}_{2}$ в диапазоне 61-74 вес. \% и относятся к высококалиевой известково-щелочной серии (I-гранитам) с содержанием суммы щелочей $\mathrm{Na}_{2} \mathrm{O}+\mathrm{K}_{2} \mathrm{O}$ от 6 до 9 вес. \%, значениями $\mathrm{K}_{2} \mathrm{O} / \mathrm{Na}_{2} \mathrm{O}$ от 1,0 до 1,5 и относительно невысокими значениями отношений $\mathrm{FeO} / \mathrm{MgO}$. Они также содержат повышенные концентрации $\mathrm{Ba}$, $\mathrm{Sr}, \mathrm{Zr}$ и $\mathrm{P}_{2} \mathrm{O}_{5}$, что является типичным для известково-щелочной серии. На вариационных диаграммах Теректинские гранитоиды формируют характерные непрерывные тренды, примеры которых показаны на диаграммах $\mathrm{CaO}$ vs. $\mathrm{SiO}_{2}$ и $\mathrm{FeO}^{\text {tot }}$ vs. $\mathrm{SiO}_{2}$ (рис. 2.20). Уменьшение содержаний $\mathrm{CaO}$ и $\mathrm{FeO}$ с ростом $\mathrm{SiO}_{2}$ объясняется фракционированием плагиоклаза и амфибола в комбинации с магнетитом. Ранняя кристаллизация магнетита из водонасыщенных расплавов в окислительной обстановке сопровождалась относительным обогащением расплавов магнием, что является типичным для известково-щелочных интрузий. Таким образом, выделение в Теректинском массиве двух разновозрастных комплексов, предложенное представителями Оттукской геологической партии [Геологическая съемка..., 1985], не подтверждается ни геохимическими, ни геохронологическими данными, так как и диоритоидное включение, относимое исследователями к силурийскому Каиндыбулакскому комплексу, и собственно гранит Теректинского массива имеют практически одинаковые возрасты: 294 и 291 млн лет, соответственно. Наличие ксенолитов метаморфических пород в гранитах Теректинского массива и характер 

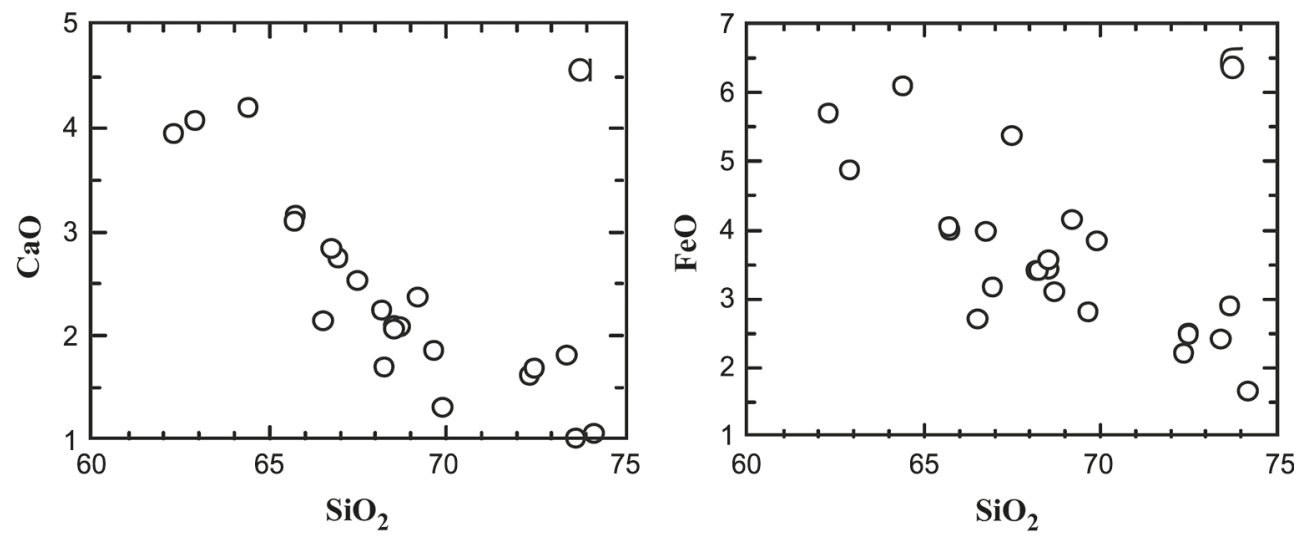

Puc. 2.20. Химические составы гранитоидов Теректинского массива на вариационных диаграммах:

$\mathrm{a}-\mathrm{CaO}$ vs. $\mathrm{SiO}_{2} ; 6-\mathrm{FeO}^{\text {tot }}$ vs. $\mathrm{SiO}_{2}$

распределения REE указывают на происхождение их из метаморфического гранатсодержащего субстрата. Возраст этого субстрата предположительно считался докембрийским, однако в многочисленных зернах ксеногенного циркона, проанализированных в четырех пробах Теректинских гранитов [Glorie et al., 2011], были установлены только раннепалеозойские и сулурийские возрасты в диапазоне 438-500 млн лет. Таким образом, гранитоиды Теректинского массива, вероятно, были выплавлены из метаморфизованного основания Срединного Тянь-Шаня в результате взаимодействия с мантийными расплавами, которые унаследовали геохимические характеристики связанных с субдукцией известково-щелочных серий. Это подтверждается положением точек составов гранитоидов Теректинского и Уланского массивов на дискриминационных диаграммах $\mathrm{Y}-\mathrm{Nb}$ и $\mathrm{Rb}-(\mathrm{Y}+\mathrm{Nb})$, где они попадают в поле островодужных гранитов (рис. 2.21).

Граниты Иныльчекского комплекса резко отличаются от Теректинского. Большая часть проб гранитов Иныльчекского комплекса характеризуется содержаниями $\mathrm{SiO}_{2} 68-70$ вес.\% и образует субщелочную $\left(\mathrm{Na}_{2} \mathrm{O}+\mathrm{K}_{2} \mathrm{O}\right.$ от 6 до 10 вес. \%, $\mathrm{K}_{2} \mathrm{O} / \mathrm{Na}_{2} \mathrm{O}$ до 1,8), умеренно глиноземистую или слабо пересыщенную глиноземом серию с очень высокими отношениями $\mathrm{FeO} / \mathrm{MgO}$. Иныльчекские граниты содержат очень высокие концентрации летучих, литофильных элементов и высокозарядных катионов (Приложение Б.2). По данным Л.И.Соломовича и Б.А. Трифонова, граниты и особенно литий-фтористые лейкограниты содержат очень высокие концентрации Li (70-800 ppm), Cs (15-150 ppm), F (0,1-1,2\%) и B (15-170 ppm) [Solomovich, Trifonov, 2002]. Таким образом, по своим геохимическим характеристикам граниты Иныльчекского комплекса очень близки к типичным А-гранитам и отличаются от стандартного гранита рапакиви [Rämö, Haapala, 1995] чуть более высокими значениями индекса 

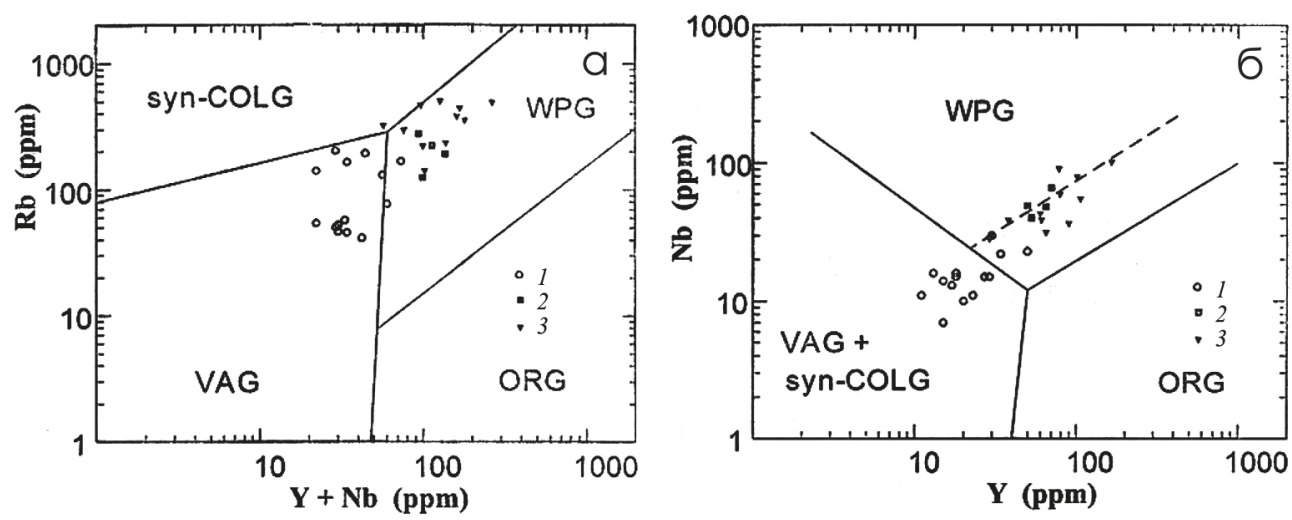

Puc. 2.21. Химические составы гранитоидов: Уланского, Теректинского (1)

и Кокшаальского (2 - кварцевые монцониты и граниты, 3 - лейкограниты) комплексов на дискриминационных диаграммах:

a - Rb-(Y+Nb); б - Y-Nb. Поля по [Pearce et al., 1984; Pearce, 1996]: WPG - внутриплитные граниты, ORG - граниты океанических хребтов, VAG — граниты вулканических дуг, syn-COLG — синколлизионные граниты

глиноземистости ASI и более высокими содержаниями бора. Однако, несмотря на относительно большой разброс концентраций $\mathrm{SiO}_{2}(65-78$ вес. \%) в Иныльчекских гранитоидах, главные петрогенные и большинство редких элементов не образуют линейных трендов на вариационных диаграммах, что затрудняет расшифровку петрогенезиса этого комплекса. Отсутствие линейных трендов, вероятно, объясняется существенным изменением химического состава в результате поздне- и постмагматических процессов. Учитывая относительную сухость расплавов, на которую указывает высокожелезистый характер гранитоидов Кокшаала и присутствие в них файялита, наиболее вероятным субстратом для образования минерализованных гранитов Иныльчекского комплекса представляются докембрийские метаморфические толщи фундамента Таримского континента.

\section{$\S$ 2.4. Обобщение результатов \\ и геодинамическая модель формирования постколлизионных интрузий Кокшаала}

Постколлизионные граниты Кокшаальского сегмента Южного Тянь-Шаня включают около 20 посткинематических интрузий, сложенных биотит-амфиболовыми гранитами, биотитовыми гранитами и литий-фтористыми топазсодержащими лейкогранитами. Внедрение гранитов происходило одновременно с мафическими породами толеитовой серии и щелочными сиенитами. По геохимическим особенностям граниты относятся к А-типу: они характеризуются 
относительно высокими значениями отношений $\mathrm{Fe} /(\mathrm{Fe}+\mathrm{Mg})$ и $\mathrm{K}_{2} \mathrm{O} / \mathrm{Na}_{2} \mathrm{O}$ и повышенными содержаниями $\mathrm{Na}_{2} \mathrm{O}+\mathrm{K}_{2} \mathrm{O}, \mathrm{Rb}$, HFSE. На дискриминационных диаграммах $\mathrm{Y}-\mathrm{Nb}$ и $\mathrm{Rb}-(\mathrm{Y}+\mathrm{Nb})$ составы гранитов проецируются в поле внутриплитных гранитов (см. рис. 2.21). На региональном уровне эволюция составов гранитоидов Кокшаала объясняется фракционированием калиевого полевого шпата и амфибола. Образование постколлизионных гранитов Кокшаала, вероятно, происходило за счет коровых субстратов, представленных докембрийскими метаморфическими породами фундамента Таримского микроконтинента.

К северу от Южно-Тянь-Шаньской сутуры, отделяющей Кокшаальский сегмент Южного Тянь-Шаня от Срединного Тянь-Шаня, находятся два крупных массива (Уланский и Теректинский) известково-щелочных гранитоидов. Их вытянутая вдоль разлома форма и наличие сининтрузивных деформаций свидетельствует об их внедрении в активную зону сдвига. Массивы сложены биотитовыми и амфибол-биотитовыми гранодиоритами с небольшим количеством габброидов, плагиогранитов и мусковитовых гранитов (Теректинский массив). Гранитоиды этих массивов резко отличаются по составу от гранитов Кокшаальского компплекса и по своим геохимическим особенностям (относительно пониженные значения отношений $\mathrm{Fe} /(\mathrm{Fe}+\mathrm{Mg})$ и $\mathrm{K}_{2} \mathrm{O} / \mathrm{Na}_{2} \mathrm{O}$, также повышенные содержания $\mathrm{Ba}, \mathrm{Sr}, \mathrm{Zr}$ и $\mathrm{P}_{2} \mathrm{O}_{5}$ ) относятся к типичной высококалиевой известково-щелочной серии (І-гранитам). Эволюция составов пород хорошо объясняется фракционированием плагиоклаза и амфибола, что является типичным для известково-щелочных серий. Наличие ксенолитов метаморфических пород в гранитоидах Теректинского массива и характер распределения REE указывают на их происхождение из метаморфического гранатсодержащего субстрата. Вероятно, эти гранитоиды были выплавлены из метаморфизованного основания Срединного Тянь-Шаня в результате взаимодействия с мантийными расплавами, которые унаследовали геохимические характеристики связанных с субдукцией известково-щелочных серий. Это подтверждается положением точек составов гранитоидов Теректинского и Уланского массивов на дискриминационных диаграммах $\mathrm{Y}-\mathrm{Nb}$ и $\mathrm{Rb}-(\mathrm{Y}+\mathrm{Nb})$, где они попадают в поле островодужных гранитов (см. рис. 2.21).

Возрасты кристаллизации интрузий Кокшаальского комплекса, установленные с помощью датирования цирконов U-Pb методом, находятся в сравнительно узком интервале 280-295 млн лет, соответствующем ранней перми и совпадающем с возрастами постколлизионных гранитов других районов Тянь-Шаня [Konopelko et al., 2006].

Две датировки, полученные для Теректинского массива (294 и 291 млн лет), свидетельствуют о том, что он формировался практически одновременно с Кокшаальскими гранитами. Несколько более древний возраст, 303 млн лет, получен нами ранее для Уланского массива [Кonopelko et al., 2006]. Раннепермский возраст Теректинского массива, внедрившегося вдоль Атбаши- 
Иныльчекского разлома, указывает на что, что к началу перми закрытие Туркестанского океана полностью завершилось, и Южно-Тянь-Шаньская сутура уже трансформировалась в зону крупного транскорового сдвига. Механизм формирования гранитоидных расплавов в подобных структурах обсуждается в конце этого параграфа.

\subsection{1. Природа коровых источников гранитов Кокшаала по изотопным данным}

Проанализированные пробы гранитов Кокшаальского комплекса характеризуются отрицательными значениями $\varepsilon \mathrm{Ndt}($ от $-6,9$ до - 1,6$)$ и мезопротерозойскими $\mathrm{Nd}$ модельными возрастами $\mathrm{T}_{\mathrm{DM}}(1,05-1,43$ млрд лет), что указывает на их происхождение из смешанных источников со значительным количеством мезопротерозойских или более древних коровых субстратов. Эти данные согласуются с результатами, полученными другими авторами для смежных районов Тянь-Шаня. На рис. 2.9 хорошо видно, что неопротерозойские метаморфические породы Северного и Срединного Тянь-Шаня попадают в поле эволюции составов нерасчлененных пород, слагающих основание Тянь-Шаня [Hu et al., 2000]. Это поле включает породы основания северного Тарима, обнажающиеся на территории Китая к западу от Куруктага и описанные как гнейсы Южного Тянь-Шаня [Hu et al., 2000]. Три пробы ордовикских гранитов, отобранные в Срединном и Северном Тянь-Шане, также характеризуются среднераннепротерозойскими $\mathrm{Nd}$ модельными возрастами $\mathrm{T}_{\mathrm{DM}}$ в диапазоне 1,14-1,53 млрд лет, что указывает на сходство докембрийского основания Тарима с фундаментом Палеоказахстана, который обнажается в Срединном и Северном Тянь-Шане.

Опубликованные недавно $\mathrm{Sr}$ и $\mathrm{Nd}$ изотопные данные по южной части среднеазиатского складчатого пояса [Chen et al., 2000; Heinhorst et al., 2000; Jahn et al., 2000] показали наличие крупных областей с ювенильной корой в Алтае, Джунгарии и Казахстане (см. рис. 2.9). Однако имеющиеся изотопные данные гранитоидов для Тянь-Шаня указывают на их происхождение из докембрийских коровых источников. Сходство изотопных составов $\mathrm{Nd}$ в гранитоидах Кокшаальского комплекса свидетельствует об их происхождении из источников, сложенных древней гомогенной континентальной корой, которая, вероятно, представляет докембрийское основание Таримского континента.

\subsection{2. Геодинамическая модель формирования постколлизионных интрузий Кокшаала}

Интрузии Кокшаальского комплекса постдатируют коллизионные деформации вмещающих пород и располагаются в виде широтного пояса, что может указывать на их связь с одним или несколькими разломами, оперяющими Южно-Тянь-Шаньскую сутуру. На постколлизионном этапе по этим разломам 


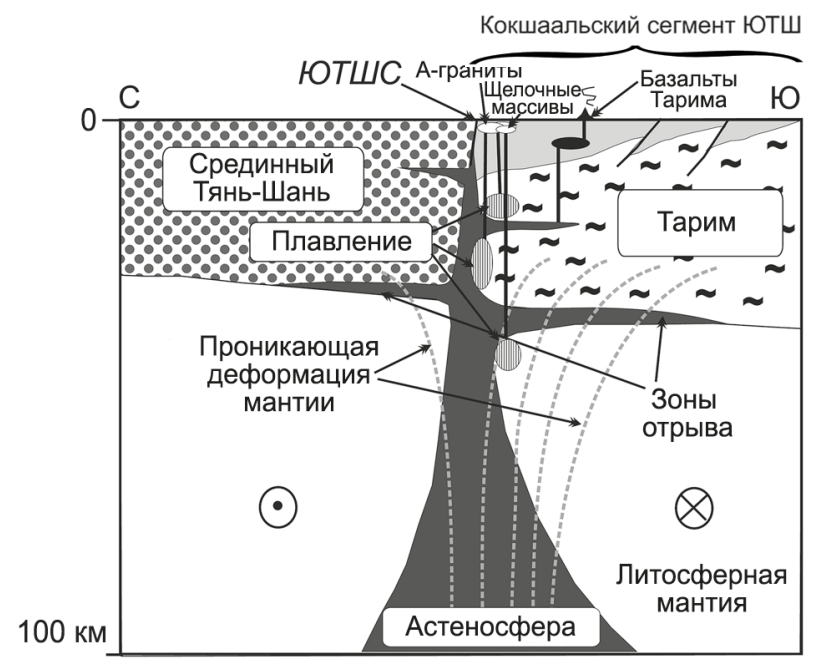

Рис. 2.22. Модель образования постколлизионных интрузий Кокшаальского сегмента Южного Тянь-Шаня. См. пояснения в тексте

происходили крупные (на десятки километров и более) латеральные смещения блоков коры, которые на отдельных участках были сопряжены с растяжением (транстенсией), что подтверждается внедрением в эти сдвиговые зоны таких массивов, как Теректинский и формированием структур типа пул-апарт, описанных в других районах Тянь-Шаня (Конопелько и др., 2011). Направление сдвигов в Кокшаальском сегменте Южного Тянь-Шаня было левосторонним [Бискэ, 1996; Бискэ, Шилов, 1998], а восточной китайской части Южного ТяньШаня - правосторонним [Laurent-Charvet et al., 2003]. Процессы, сопровождающие крупные транскоровые сдвиги, были недавно рассмотрены в ряде работ [Leloup, Kienast, 1993; Maxson, Tikoff, 1996; Teyssier, Tikoff, 1998; Titus et al., 2007]. В этих работах было показано, что перенос сдвиговой составляющей от мантии к коре сопровождается возникновением субгоризонтальных зон отрыва в нижней и средней коре [Teyssier, Tikoff, 1998]. Таким образом, крупные сдвиги, сопряженные с растяжением на постколлизионной стадии (транстенсия), приводят к подъему горячего вещества астеносферы и обеспечивают привнос тепла в нижние и средние горизонты коры. С нашей точки зрения, эта модель, схематически показанная на рис. 2.22, также позволяет объяснить механизм возникновения интрузий Кокшаальского комплекса. Согласно этой модели, подъем горячего вещества астеносферы вызвал плавление коры и внедрение гранитоидных интрузий, которые обнажаются на современном эрозионном срезе в Кокшаале. Коровые субстраты, которые подвергались плавлению, были представлены докембрийскими метаморфическими породами фундамента и кластическими осадками континентального склона 
Таримского микроконтинента, который в результате герцинской коллизии поддвигался на север под Срединный Тянь-Шань. Мафические породы толеитовой серии, ассоциирующие с постколлизионными гранитоидами, могут представлять собой материал астеносферной мантии, подъем которой обеспечил привнос тепла и плавление докембрийской коры Тарима, и быть родственными плато-базальтам Тарима, формирование которых также происходило в ранней перми [Jiang et al., 2004]. Предложенная модель также объясняет одновременное образование щелочных расплавов и карбонатитов, которое могло происходить в результате взаимодействия горячего ювенильного вещества астеносферы с древней литосферной мантией, подстилающей Тарим (см. рис. 2.22).

Внедрение интрузий Кокшаальского комплекса в обстановке постколлизионных сдвиговых смещений должно было бы привести к возникновению сининтрузивных деформаций, которые часто наблюдаются в связанных с зонами сдвига интрузиях других районов Тянь-Шаня [Конопелько и др., 2011]. Наличие таких массивов, удлиненных параллельно главным субширотным разломам, указывает на то, что подобные зоны сдвига действительно контролировали внедрение постколлизионных интрузий [Konopelko et al., 2006]. Однако, поскольку сининтрузивные деформации не проявлены в интрузиях Кокшаальского комплекса, мы предполагаем, что их возникновение могло быть связано с вязкой зоной сдвига, находящейся на глубине, и субширотное расположение пояса постколлизионных интрузий является единственным свидетельством существования этой зоны сдвига на современном эрозионном срезе. 